\title{
Organizational Structures and the Improvement of Working Conditions in Global Supply Chains: Legalization, Participation, and Economic Incentives
}

\section{Citation}

Zhou, Yanhua, Jodi L. Short, and Michael W. Toffel. "Organizational Structures and the Improvement of Working Conditions in Global Supply Chains: Legalization, Participation, and Economic Incentives." Harvard Business School Working Paper, No. 18-003, July 2017.

\section{Permanent link}

http://nrs.harvard.edu/urn-3:HUL.InstRepos:33840635

\section{Terms of Use}

This article was downloaded from Harvard University's DASH repository, and is made available under the terms and conditions applicable to Open Access Policy Articles, as set forth at http:// nrs.harvard.edu/urn-3:HUL.InstRepos:dash.current.terms-of-use\#OAP

\section{Share Your Story}

The Harvard community has made this article openly available.

Please share how this access benefits you. Submit a story.

\section{Accessibility}


Organizational Structures and the Improvement of Working Conditions in Global Supply Chains: Legalization, Participation, and Economic Incentives

Yanhua Z. Bird Jodi L. Short Michael W. Toffel

Working Paper 18-003 


\title{
Organizational Structures and the Improvement of Working Conditions in Global Supply Chains: Legalization, Participation, and Economic Incentives
}

\author{
Yanhua Z. Bird \\ Harvard Business School \\ Jodi L. Short \\ UC Hastings College of the Law \\ Michael W. Toffel \\ Harvard Business School
}

Working Paper 18-003 


\section{Organizational Structures and the Improvement of Working Conditions in Global Supply Chains: Legalization, Participation, and Economic Incentives ${ }^{\dagger}$}

\author{
Yanhua Z. Bird \\ Harvard Business School \\ ybird@hbs.edu
}

\author{
Jodi L. Short \\ UC Hastings College of the Law \\ shortj@uchastings.edu
}

\author{
Michael W. Toffel \\ Harvard Business School \\ $\underline{\text { mtoffel@,hbs.edu }}$
}

July 9, 2017

Exploitive working conditions have spurred the development of formal organizational structures that deploy mechanisms including legalization - adherence to a set of law-like rules and procedures - and worker participation to improve labor standards in global supply chains. Yet little is known about whether these structures are associated with improved working conditions, especially in organizations in which they compete with productivity-driving economic incentives. Drawing on the economic sociology of law and organizations and theories of organizational learning, we investigate whether and how these formal organizational structures, individually and in combination, are associated with improved working conditions. Using data on 3,276 suppliers in 55 countries, we find greater improvement at suppliers that adopt legalization structures (operationalized as management system standards) and worker participation structures (unions) and find that the combination of these structures amplifies improvement. We find less improvement at suppliers with organizational incentive structures meant to increase worker productivity (piece-rate pay), but also find that this negative relationship is attenuated by organizational legalization and worker participation structures. These findings challenge existing theories of decoupling by showing how these organizational structures can be credible signals for improvement and can also be coupled with organizational changes via processes of organizational learning, even in the face of intense efficiency demands. Furthermore, our findings suggest important strategic considerations for managers selecting supplier factories and provide key insights for the design of transnational sustainability governance regimes.

\footnotetext{
${ }^{\dagger}$ We thank participants at the Social Innovation and Change Workshop at Harvard Business School and Harvard Kennedy School and the Boston Area Global Labor Standards Meeting at MIT Sloan School of Management for insightful comments on drafts of this article. We gratefully acknowledge the research assistance of Melissa Ouellet and financial support from the Division of Research and Faculty Development at the Harvard Business School.
} 


\section{Organizational Structures and the Improvement of Working Conditions in Global Supply Chains: Legalization, Participation, and Economic Incentives}

Suppliers to global value chains face multiple pressures from their institutional environment. Suppliers are subject to the formidable efficiency demands of the global value chain to produce ever more rapidly and at ever lower margins. Since the 1980s, following the liberalization of trade, the supply chain revolution, and the shareholder value movement, global outsourcing has become the principal production strategy of multinational companies (MNCs) (Bartley 2005, Gereffi et al. 2005). The product-cost economics of global production has pushed low-value-added segments of generic services and volume production to suppliers in the Global South, which compete principally on labor costs (Gereffi and Christian 2009), resulting in a "race to the bottom" in labor standards (Bartley 2005, Gereffi et al. 2005). Global buyers' stringent sourcing practices magnify the efficiency pressures on suppliers and, many argue, have contributed to the sweatshop conditions that prevail in many supplier factories (Anner et al. 2013).

At the same time, suppliers face increasingly forceful demands from global buyers to improve conditions for their workers. MNCs are, themselves, subject to numerous institutional pressures to raise labor standards in their supply chains (Distelhorst et al. 2016, Okhmatovskiy and David 2011). Highprofile catastrophes, like the Rana Plaza building collapse that killed more than 1,000 factory workers in Bangladesh, have attracted worldwide attention to hazardous supply chain working conditions, increasing reputational pressure on global brands to improve them. Shareholder resolutions demanding supply chain due diligence and observance of international human rights norms command higher levels of support each proxy season. Increasingly, MNCs face domestic and international legal obligations to monitor and report on conditions in their supply chains and to adhere to the voluntary commitments they make to improve supply chain working conditions.

MNCs have responded to the legitimacy pressures in their institutional environment in part by pressuring their suppliers to adopt organizational structures, policies, and procedures to improve 
working conditions. The most common of these structures promote the "legalization" of supplier labor practices through mechanisms like codes of labor conduct, monitoring requirements, and privately certified management systems, which require suppliers to adhere to a set of law-like rules and procedures (Sutton and Dobbin 1996). Furthermore, many brands, consultants, and other stakeholders promote the adoption of organizational "worker participation" structures, from grievance procedures to employee unions, that provide formal channels for workers to voice concerns and contribute to supplier decision-making processes. These strategies rest on the understanding that worker involvement is essential to the sustainable improvement of supply chain labor standards (Rodriguez-Garavito 2005, Yu 2009). Indeed, many suppliers have adopted various types of organizational "legalization" and "participation" structures in response to buyers' legitimacy demands. Yet these legitimacy-enhancing structures exist in tension with the relentless efficiency demands of the global value chain. Moreover, they often compete within supplier firms with organizational structures, such as incentive payment to spur worker productivity, that have been adopted to meet these efficiency demands.

The extensive literature on decoupling suggests that under such conditions, legitimacy-related organizational structures will yield to efficiency demands. First, research has long theorized and empirically documented that organizational structures adopted to gain legitimacy will tend to be implemented symbolically and decoupled from organizational practices that advance the technical or efficiency-related demands of production work (Bromley and Powell 2012, Boiral 2007; Meyer and Rowan 1977). Second, the literature suggests that decoupling is particularly likely in less-elaborated institutional environments, where efficiency demands are strong and institutional pressures to implement legitimacy-related structures are weak (Meyer and Rowan 1977). Research has also identified key factors that inhibit decoupling, such as coercive pressures from states and politically mobilized civil society actors (e.g., Marquis et al. 2016, Short and Toffel 2010), but these institutional pressures are often lacking in the emerging economies where many suppliers are located. Finally, the implementation of legitimacy-related structures requires organizational resources that many suppliers lack (Bromley and Powell 2012, Lim and Tsutsui 2012). As has long been observed, it is "much easier to adopt the latest 
structural forms than to make them work effectively," particularly when they are "inconsistent with local practices, requirements, and cost structures" (Meyer et al. 1997: 154), as in the home countries of many suppliers. This body of research suggests that organizational structures adopted by suppliers to improve labor standards will be, at best, ceremonial window dressing "implemented, evaluated, and monitored so weakly that they do little to alter daily work routines" designed to satisfy efficiency demands (Bromley and Powell 2012, Lim and Tsutsui 2012, Meyer and Rowan 1977).

While this prevailing theoretical framework contains important and cautionary lessons about the acute threat of decoupling in less-elaborated institutional environments, it provides little insight into when coupling is possible and how it might vary across firms operating in these environments. This is a significant gap in the literature, as MNCs increasingly seek to outsource the legitimacy pressures they face down the supply chain to suppliers that are subject to fewer institutional pressures. Research on supply chain labor standards suggests that it is untenable to dismiss the organizational structures adopted in these environments wholesale as myth and ceremony. Studies consistently have shown that, on average, suppliers that adopt various types of legalization and participation structures do, in fact, improve their working conditions over time (Ang et al. 2012, Locke et al. 2007, 2013, Nadvi et al. 2011, Shea et al. 2010, Toffel et al. 2015). These findings belie a straightforward story of symbolic or cynical adoption. Unfortunately, the institutional literature provides limited tools with which to understand variations in the coupling and decoupling of organizational legitimacy structures in the absence of commonly cited institutional pressures.

To fill this gap in the literature, we turn our focus to the internal organizational dynamics of supplier firms. Drawing on the economic sociology of law and organizations and theories of organizational learning and (Crossan et al. 1999, Cyert and March 1963, Parker 2002, Selznick et al. 1969), we argue that legitimacy structures that provide opportunities for organizational learning about extant working conditions and ways to improve them are, in fact, likely to be associated with the actual improvement of working conditions. Legitimacy structures can be credible signals for improvement and can also be coupled with organizational changes via processes of organizational learning. While it might 
not be feasible to change the institutional conditions of the supply chain environment in the near term, organizational structures that promote learning can build suppliers' organizational capacities to implement legitimacy structures, enhancing the likelihood that those structures will then be coupled with organizational practices. In addition, we argue that coupling outcomes must be understood in light of dynamic relationships among organizational structures, including how organizational legitimacy structures interact with one another as well as with organizational incentive structures that have been adopted to meet efficiency demands but that compete with legitimacy demands.

We test our theories on a proprietary dataset from a large social auditing firm that contains 8,323 audits of 3,276 suppliers in 55 countries conducted between 2012 and 2015. We find greater improvement in working conditions at suppliers that adopt legalization and worker participation structures and we find that the joint presence of these structures amplifies the improvement. We find less improvement at suppliers with organizational incentive structures meant to increase worker productivity, but we also find that this negative association is attenuated by organizational legalization and worker participation structures. These findings suggest that legitimacy-oriented organizational structures can be "more than merely symbolic" (Short and Toffel 2010), even in the face of strong efficiency demands, and can, in fact, moderate those demands.

This study contributes several important insights to the literature on decoupling. First, it demonstrates the possibility of coupling in a context characterized by boundary conditions that have gone largely unquestioned in the literature. By establishing that coupling can occur in firms that are subject to intense efficiency demands in emerging economies characterized by weak civil society institutions and limited state labor regulatory capacity, our research suggests the need to reconsider the conditions under which coupling occurs. Second, our focus on internal organizational dynamics significantly augments the literature on decoupling, which has emphasized the influence of external institutional factors. We bring in the organizational learning perspective to theorize that formal organizational structures that provide mechanisms for learning can either drive organizational changes or signal which organizations are capable of change. To our knowledge, ours is the first large-scale, 
quantitative study of coupling dynamics inside organizations, building on a handful of studies that qualitatively investigate the processes of coupling and decoupling within organizations (Bartley and Egels-Zandén 2016, Boiral 2007, Hallett 2010, Overdevest 2010, Tilcsik 2010). In this way, our study likewise builds on research in the economic sociology of law and organizations examining how “insecure or precarious values" (Rees 1988:10) like worker protection become instilled in profit-driven organizations through internal structures and processes that facilitate information flows, interconstituency interactions, and reflection (e.g., Parker 2002, Selznick et al. 1969, Teubner 1983).

Third, we extend these studies, as well as the broader decoupling literature, by examining how multiple and potentially conflicting organizational structures interact with one another. To date, studies have tended to examine the conditions under which a single, isolated organizational governance structure is coupled to or decoupled from organizational practices. But this approach ignores the complex and multifarious nature of these structures inside the organization. Firms face multiple and competing institutional demands that get sedimented into multiple and competing layers of organizational structure. It is crucial to appreciate the internal interaction of these structures in order to understand whether and when they will be coupled to organizational practices. Finally, while the specter of efficiency demands looms large in the background of decoupling studies, there has been no systematic empirical investigation of the relationship between efficiency demands and the decoupling of organizational legitimacy structures. Our investigation of the organizational incentive structures that operationalize environmental efficiency demands is a novel and important attempt to address fundamental questions about the relationship between legitimacy and efficiency imperatives that lie at the core of this literature.

\section{ORGANIZATIONAL STRUCTURES GOVERNING GLOBAL SUPPLY CHAINS}

Although an extensive literature documents the decoupling of organizational governance structures and practices that conflict with efficiency demands, less is known about whether and when these structures become coupled in ways that meaningfully shape organizational practices over time, 
particularly in organizations that face intense efficiency pressures. Recently, there have been growing calls for more attention to the organizational phenomenon of coupling - the process by which organizational structures adopted symbolically take on substance by meaningfully changing organizational practices (Bromley and Powell 2012, Hafner-Burton and Tsutsui 2005, Hallett 2010, Overdevest 2010). While a handful of qualitative studies have documented how the micro-level interactions of individual organizational actors can couple formal organizational structures to practices (Fiss and Zajac 2004, Hallett 2010, Overdevest 2010, Tilcsik 2010), the bulk of studies finding coupling have attributed it to coercive institutional pressures like state power and civil society political mobilization. For instance, research has identified regulatory attention and enforcement as important factors that can reduce the decoupling of organizational commitment and practice (Dobbin and Kelly 2007, Marquis and Qian 2014, Short and Toffel 2010). Studies of private organizations' implementation of human rights or corporate social responsibility (CSR) policies have suggested that institutional pressures emanating from activists or the press can likewise increase companies' commitments to better practices (Fransen 2012, Lim and Tsutsui 2012, Marquis et al. 2016, Seidman 2007, Toffel et al. 2015). In the supply chain context, for example, Bartley and Egels-Zandén (2015) identified several cases in which unions politically mobilized to leverage global brands' CSR commitments to improve conditions for workers. However, this literature provides little insight into the coupling of organizational governance structures absent coercive pressures brought to bear by the state or civil society actors.

A substantial body of literature theorizes and demonstrates how formal organizational structures and routines shape organizational practices via learning processes. Organizational learning theories posit that formal structures can help organizations to learn — that is, to adjust their own practices — by creating mechanisms to integrate feedback from subsequent events and experiences (Crossan et al. 1999, Cyert and March 1963, Fiol and Lyles 1985). Although the organizational learning research is currently focused on knowledge generation and transfer at the team and interorganizational levels (e.g., (Yang et al. 2010), the aforementioned early scholarship on formal structures provides important insights into 
how certain organizational legitimacy structures might become coupled with organizational practices by formalizing and integrating organizational learning.

The organizational learning perspective is central to research on how legal and social norms become institutionalized in profit-driven companies through formal organizational structures. Since Selznick et al. (1969), scholarship has theorized that formal structures can build normative considerations into corporate decision-making and constrain contrary corporate practices by (a) establishing decision-making mechanisms and routines that build in normative concerns (Parker 2002, Rees 1988); (b) empowering constituencies in the organization that are invested in achieving normative outcomes (Parker 2002, Rees 1988, Selznick 1992); and (c) generating normative scripts for motivating and justifying organizational actions (Dobbin and Sutton 1998). However, few of these studies have empirically assessed whether the adoption of formal structures actually achieved their ostensible normative goals. Moreover, research in this domain has been conducted in highly institutionalized environments and there is broad consensus in the literature that coupling requires external pressure from either government or third-party stakeholders (Ayres and Braithwaite 1992, Parker 2002).

Below, we first theorize how legitimacy structures (i.e., legalization and worker participation structures) facilitate organizational learning, a core mechanism by which they can signal intent to improve and potentially become coupled with suppliers' improvement of working conditions. We then discuss the interplay of these two types of legitimacy structure, focusing on how worker participation can enhance legalization structures by integrating communication and feedback into the organizational learning processes. Next, we argue that efficiency structures like productivity-driven economic incentives will dampen motivation and opportunities for organizational learning, undercutting improvement. Finally, we theorize how legitimacy structures can temper the negative association of efficiency structures and improvement in working conditions by reducing the obstacles to organizational learning. 


\section{Legalization Structures}

Legalization refers to the use of law-like rules and practices to regulate workplace relationships and production practices (Sutton and Dobbin 1996). One of the most prominent legalization strategies to raise supply chain labor standards has been to require suppliers to obtain certification to a management system standard attesting to the adequacy of their labor practices and conditions. Organizations such as Fairtrade, Social Accountability International, the International Organization for Standardization, and numerous industry-specific initiatives in industries such as apparel, electronics, and mining promulgate management system standards and specify how suppliers are to be independently audited and certified to be in adherence. While certification has long been considered a way to signal the quality of a supplier's products or processes, it is increasingly being deployed as a "mode of social regulation" (Bartley 2011) that seeks to raise standards in global supply chains by changing suppliers' managerial and production practices and providing support and market benefits to suppliers that maintain sufficiently high standards. However, there is substantial skepticism and uncertainty about whether even well-designed certified management systems can improve work (Seidman 2007).

To date, research on certification has focused on assessing whether it is a credible signal of superior practices by comparing the working conditions at certified and noncertified establishments at a given point in time (e.g., Cafaggi 2012, Egels-Zandén 2007, Locke 2013, Vinodkumar and Bhasi 2011). In contrast, we investigate whether, over time, suppliers certified to management system standards exhibit more improvement in working conditions than noncertified suppliers. Drawing on organizational learning theories that emphasizes the role of formal structures such as diagnostic systems (Crossan et al. 1999, Cyert and March 1963), we hypothesize that certified management systems will be associated with improvement because they provide organizational mechanisms for self-monitoring and selflearning. Most certified management system standards require an explicit commitment to continuous improvement, as well as the implementation of ongoing self-monitoring and self-corrective procedures to identify and remedy instances of nonconformance and to improve processes on an ongoing basis. For instance, a leading management system standard focused on process quality requires firms to 
"continually improve ... through the use of ... audit results, analysis of data, corrective and preventive action and management review."1 A leading management system standard focusing on working conditions in global supply chains likewise requires continuous improvement in several ways; for instance, by requiring companies to ensure that "regular and comprehensive internal audits take place" 2 and to "implement remedial and corrective action and allocate adequate resources appropriate to the nature and severity of any non-conformance identified."3

Such continuous improvement procedures can provide a mechanism for legalization structures to build normative considerations into organizational decision-making routines (Parker 2002, Selznick et al. 1969) and thus to improve working conditions. First, the self-monitoring processes and periodic internal auditing required by these management system standards can lead companies to detect flawed management processes that may undermine compliance with certain labor standards. For example, internal audits may reveal the absence of procedures to appropriately label and store hazardous chemicals and to keep aisles clear, which increases the probability and magnitude of injuries. Audits can reveal operational risks, such as the lack of machine guarding or the failure to maintain training records, allowing managers to mitigate the risk of worker injuries and improve workplace conditions. Second, management system standards provide opportunities for managers to learn about best practices and to perform gap analyses with their own practices, which can motivate improvement. Furthermore, even if participation in management system standards is initially intended as merely a weakly symbolic commitment, it can sometimes be leveraged to spur meaningful change. Studies have shown that CSR statements may serve as the "aspirational talk" that motivates the company to recognize and then try to close the gap between its words and its actions (Christensen et al. 2013) and that supplier codes of conduct can provide workers' advocates with political ammunition to demand that suppliers adhere to their commitments (Bartley and Egels-Zandén 2016).

\footnotetext{
${ }^{1}$ International Organization for Standardization 2000: 13

${ }^{2}$ Council on Economic Priorities Accreditation Agency 1999: 36-37

${ }^{3}$ Ibid.
} 
However, because we do not directly observe these mechanisms, it is important to note that even if certified management systems cannot be causally identified as driving improvement at supplier organizations, the fact of certification can nonetheless serve as a credible signal of a supplier's capacity and intent to improve. As discussed above, formal structures can not only drive organizational learning, but also signal the formalization of ongoing organizational learning (Crossan et al. 1999, Cyert and March 1963, Fiol and Lyles 1985). Firms that are "eager learners/improvers" are more likely to institute certified management systems in the first place. Moreover, adopting these formal structures can reflect the culmination of ongoing organizational learning and improvement endeavors and thus can signal a firm as a particularly eager and capable learner. Thus, we hypothesize:

H1: Suppliers certified to management system standards will improve working conditions more than noncertified suppliers.

\section{Worker Participation Structures}

Academics have long argued that substantial improvements in supply chain working conditions require meaningful worker participation (Rodriguez-Garavito 2005, Yu 2009). Advocacy groups have stressed that worker involvement is essential to the sustainable improvement of supply chain labor standards (Yu 2009: 239). And leading multinational brands increasingly demand that their suppliers develop avenues for promoting worker participation, from grievance procedures to unions. For instance, Target states in its supplier code of corporate responsibility that the company "expects suppliers to productively engage workers and value them as critical assets to sustainable business success. This includes respecting the rights of workers to freely associate, engage in worker participation groups and submit individual grievances without fear of retaliation." Reebok requires its suppliers to develop worker empowerment programs that train workers on their legal rights, provide channels for them to communicate with both management and factory monitors about concerns, and support initiatives to foster collective worker representation (Yu 2009). Inditex, parent of a portfolio of global brands including Zara, recently partnered with IndustriALL Global Union to position "freedom of association and the right to collective bargaining as the central pillars of a sustainable supply chain, since these 
rights provide workers with the necessary mechanisms to control and strengthen their labour rights" (Inditex 2017).

Unions have historically been the most important formal channel for worker participation in management processes. To date, scholars and advocates, particularly in the Americas and the European Union, have focused on unions' political role in raising labor standards by rectifying power imbalances between workers and their employers (Morantz 2015, Reilly et al. 1995, Rodriguez-Garavito 2005).

However, unions play a different role in many of the developing countries where supply chain factories are located. First, workers in many such countries are routinely denied bottom-up representation of their choosing (Anner 2012, Anner and Liu 2016, Bartley and Egels-Zandén 2015). Second, employers that permit unions often do so merely to curry political favor with the authoritarian state rather than to actually give workers a meaningful voice (Brown and O'Rourke 2007; Friedman and Lee 2010). In countries such as China and Vietnam, unions are considered extensions of the government apparatus rather than independent representatives for workers' interests (Anner and Liu 2016), raising serious questions about whether they will be associated with improvements in labor standards.

Yet, by focusing on the relative political impotence of unions in certain environments, these accounts have neglected other important functions unions can play in supplier organizations. There is evidence that unions can play effective communication and education roles that enable workers to participate in improving production systems and rectifying workplace issues. First, unions can provide an additional channel for workers to bring hazards to management's attention, one that is often safer and more effective than doing so directly. For example, in some Chinese factories, unions have input on monitoring occupational health and safety conditions by having a union member serve as a labor protection investigator on the shop floor (Chen and Chan 2004). Such practices facilitate employee reports of health and safety concerns. Furthermore, research has found that unions put forth proposals to remedy unsafe and hazardous conditions (Chen and Chan 2004) and cooperate directly with management to monitor and correct those conditions (Reilly et al. 1995, Walters 2006). Second, in many factories, unions provide training programs and education materials for workers. In China, studies 
have found that unions are often tasked with educating employees on workplace conditions and workers' wellbeing, which can help train frontline workers to identify and protect themselves from occupational hazards (Dong et al. 2004, Nissen et al. 2008). Indeed, research has shown that in unionized factories, workers are more aware of dangerous practices (Gillen et al. 2002).

In the organizational learning process, integrating communication and feedback from key relevant parties is critical (Crossan et al. 1999, Cyert and March 1963, Fiol and Lyles 1985). Formal structures like unions can empower interested and motivated constituencies in the organization to convey critical information about workplace conditions (Parker 2002, Rees 1988, Selznick 1992), fostering organizational learning. As discussed above, by engaging and educating workers, unions can assist in the identification and rectification of workplace issues, thus improving working conditions.

Finally, as with certifications, the existence of unions as a formal organizational structure can credibly signal which firms are most likely to improve working conditions even if the unions themselves do not actually drive improvement. Unions may indicate suppliers' attention to and consideration of workers' interests and a willingness to learn about and rectify workplace issues. We argue that suppliers so disposed are more likely than others to improve working conditions.

For all these reasons, we hypothesize:

H2: Unionized suppliers will improve working conditions more than non-unionized suppliers.

\section{Do Worker Participation Structures Enhance Legalization Structures?}

Many have argued that management systems to protect workers are more likely to succeed when they are supported by workers who can provide an additional layer of monitoring, information, and advocacy (Anner et al. 2013, Rodriguez-Garavito 2005). In the context of global supply chain factories, we argue that unions can complement legalized organizational structures such as certified management systems by expediting and augmenting organizational learning processes. First, as noted, unions often

play an important educational and communicative role, which can raise workers' awareness of the requirements of certain certification programs (O’Rourke 2003, Rodriguez-Garavito 2005, Yu 2009).

Such awareness can contribute both to workers' adherence to codes of conduct and engagement in 
implementing management systems in ways that will improve working conditions; for instance, by identifying potential issues, assessing risks, and updating objectives and procedures. Most certified management systems require ongoing internal assessment, dialogue, and updating of goals and standards. Working conditions are more likely to receive attention as a part of this process when there is a formal channel, such as a union, for workers to provide input into organizational decisions. For all these reasons, we hypothesize:

H3: Certification to a management system standard will be associated with greater improvement in working conditions for unionized suppliers than for non-unionized suppliers.

\section{Incentive Structures}

As suppliers attempt to meet the legitimacy demands of global buyers for improved working conditions by adopting organizational legalization and participation structures, they must also address efficiency demands. Many suppliers respond by adopting internal incentive structures to promote lowcost, high-volume production (Anner et al. 2013, Bartley 2005, Gereffi et al. 2005, Locke et al. 2013). Specifically, many suppliers use piece-rate (or piecework) payment to incentivize productivity by giving workers a direct share of the economic gain for each incremental productivity gain (Burawoy 1983, Lazear 2000, Williamson 1985).

We argue that, for several reasons, a supplier's adoption of such productivity incentive structures is likely to impede the improvement of working conditions. First, workers with such incentives may be more reluctant to learn and adopt practices that would improve working conditions but reduce productivity. For instance, some health and safety procedures — such as participating in emergency training, wearing personal protection equipment (e.g., masks and steel-mesh gloves), and using machine guards - can slow the pace of work. Ethnographic research on logging workers shows that piece-rate workers are willing to accept what they perceive as the low probability of being injured on the job, even though this could trigger substantial income loss, but refuse to accept the small but certain economic loss caused by adhering to health and safety procedures (Patterson 2007). Similarly, research shows that piece-rate workers are more reluctant to take breaks (Lilley et al. 2002), which may 
make them more susceptible to mistakes and injuries and may, itself, violate some labor codes of conduct. Studies have also shown that piece-rate payment increases stress and encourages risk taking (Patterson 2007, Sundstroem-Frisk 1984, Weyman et al. 2003). Just as incentives to cut corners to produce more quickly are associated with inferior working conditions, they are also likely to hinder workers' engagement in practices that would improve those conditions.

Second, productivity incentives such as piece-rate payment have been shown to attract workers with shorter expected tenure (Heywood and Wei 1997), whereas many working condition improvements require investments, such as training on how to prevent repetitive stress injuries and how to respond to emergencies, that yield longer-term benefits. Workers who do not expect to be around to benefit from improved working conditions may be less likely to invest effort to achieve them.

Third, employing productivity incentives signals that management is particularly devoted to high productivity (Dohmen and Falk 2011, Holmstrom and Milgrom 1991, Prendergast 1999) and is therefore likely to be focused on maintaining or enhancing productivity rather than on mitigating its negative social effects. In this context, managers are unlikely to invest substantial resources to remediate workplace issues that would improve working conditions, particularly if these investments conflict with short-term productivity goals. For these reasons, we hypothesize:

H4: Suppliers with productivity incentives will improve working conditions less than other suppliers.

\section{Can Legalization and Worker Participation Temper Productivity Incentives?}

As discussed previously, the pursuit of high-volume production and short-term economic rewards under productivity incentives can discourage practices that would improve working conditions at some cost to productivity. However, certification to management system standards can help suppliers develop and sustain management practices that will ultimately improve productivity and reduce the marginal costs of complying with certain labor codes, which, in turn, expedites organizational learning. For example, the adoption of quality management systems may result in improved production planning and reduced cycle time (Appelbaum 2000, Dunlop and Weil 1996), which, in turn, may reduce the 
pressure on workers to work overtime to meet delivery deadlines (Locke et al. 2009). Thus, by improving production process management, suppliers may reduce the cost of remediating certain violations of workplace standards. Furthermore, the management process improvements associated with lean production have been shown to increase productivity and quality (Holweg 2007) while also reducing noncompliance with supplier codes of conduct (Distelhorst et al. 2016). Such management practices can alleviate the underlying tension between short-term economic rewards and labor code compliance in high-productivity-oriented contexts. Therefore, we hypothesize:

H5a: Certification to management system standards attenuates the negative relationship between productivity incentives and improvement in working conditions.

We posit that unionization, too, can attenuate the negative relationship between productivity incentives and working condition improvement. First, unions often play an important educational role that raises workers' awareness of occupational hazards, the costs they would bear from workplace injuries, and their legal rights (Meng and Smith 1993, Morse et al. 2003). Such awareness can countervail the incentive to cut corners in pursuit of rapid production. Second, unions are associated with longer job tenure (Bender and Sloane 1999, Freeman 1980), which facilitates managers' investment in worker training and other programs that improve both working conditions and productivity over the long term. Workers may be more likely to support such practices if they expect to be around long enough to benefit from them, which can, in turn, increase the likelihood that managers will invest in those practices. Managers, too, stand to gain from lower turnover. Therefore, we hypothesize:

H5b: Unionization attenuates the negative relationship between productivity incentives and improvement in working conditions.

\section{DATA AND MEASURES}

We test our hypotheses using a proprietary dataset from a large social auditing firm that required anonymity as a condition of sharing its data. The dataset includes all audits against a single code of conduct that the firm conducted from 2012 through 2015. The dataset also provides information about each audited supplier, the audit team, and the buyer on whose behalf the audit was conducted. 
Because our empirical specification includes a supplier's focal (current) audit and its prior audit, our estimation sample is limited to those suppliers with at least two audits in our dataset. Our estimations are based on 4,887 focal audits of 3,276 suppliers in 55 countries on behalf of 102 buyers from 11 countries. Because our specification also relies on data from each supplier's prior audit, our analysis is based on a total of 8,323 focal and prior audits ${ }^{4}$. Table 1 reports the industry composition of our sample: the most common industries are hardlines (merchandise such as furniture, household utensils, and home décor), apparel, and electronics. As Table 2 shows, most of the audited suppliers are in China; the rest are elsewhere in Asia (e.g., India, Indonesia, Cambodia, Vietnam), Europe (e.g., Italy), and the Americas (e.g., Mexico, the United States).

\section{Dependent Variable}

In our context, audit teams assess the extent to which suppliers' workplace conditions meet a single code of conduct that specifies maximum working hours and minimum wages, occupational health and safety practices, and environmental management practices, etc. This standard is highly consistent with international consensus standards such as the International Labour Organization (ILO) core labor standards. Each audit results in a working condition score that ranges from 0 to 100, with higher scores indicating better compliance. In our sample, scores range from 19 to 100 , the average being 79. Our dependent variable measures a supplier's improvement between its prior and focal audits, which we calculate by subtracting the prior audit score from the focal audit score. Larger values indicate greater improvement. In our sample, improvement averages 6 and ranges from -62 to 67 .

\section{Independent Variables}

We code certification to a management system standard as 1 when a supplier is certified to at least one standard — such as SA8000, WRAP, ISO 9001, or OHSAS 18001 — at the time it was audited, ${ }^{5}$ and 0 otherwise. Workers' union, another dichotomous variable, equals 1 when the supplier is unionized,

\footnotetext{
${ }^{4}$ Note that 8,323 is less than twice the number of focal audits because some suppliers were audited more than twice in our sample period, which results in 1,451 audits serving as a focal audit in one observation and as a prior audit in another observation.

${ }^{5}$ For the full list of management system standards, see Table A4 in Appendix A.
} 
as recorded by the auditor, and 0 otherwise. We identify factories that use productivity incentives by coding piece-rate payment, a dichotomous variable, as 1 when the supplier pays its frontline workers on a piece rate and 0 otherwise. ${ }^{6}$ Data for these three variables were obtained from the audit database. In our model, we use lagged values of these variables so that they pertain to the supplier's prior audit in order to examine their effect on subsequent improvement. Fifteen percent of these prior audits were conducted at certified suppliers, 26 percent at unionized suppliers, and 11 percent at suppliers that use piece-rate payment.

\section{Audit-level Control Variables}

We control for several audit-level factors that might also influence the extent to which suppliers improve their working conditions. We include working condition score (prior audit) to account for the fact that suppliers with lower prior scores have more room for improvement — and might face less expensive improvement opportunities — than suppliers that already had superior working conditions.

Whether or not the supplier is paying for the audit can also influence auditors' reports because of the conflict of interest that might lead auditors to report fewer violations when the audit is paid for by the supplier rather than the buyer (Short et al. 2016). To account for this, we create two dummy variables, paid by buyer (prior audit) and paid by buyer (focal audit), to distinguish those audits from those paid for by the supplier itself.

We control for several characteristics of audit teams that prior research has shown can affect audit scores (Short et al. 2016). First, we create dummy variables to control for the gender composition of the audit teams that conducted the supplier's prior and focal audits: all-female audit team and mixedgender audit team, with all-male audit team as the omitted category. Second, we control for audit team average age for the prior and focal audits, based on auditor age data provided by the auditing firm. Third,

\footnotetext{
${ }^{6}$ It is possible that some factories in our sample that do not use piece-rate pay might supplement their hourly wage scheme with other productivity incentives, such as production bonuses, that we do not observe in our data.

However, to the extent that this is occurring, our estimated coefficient on piece-rate payment should be considered the lower bound of the true impact of high-powered incentives. This is because our estimates identify the difference between factories that rely on piece-rate payment and factories that rely on low-powered incentives, either alone or in combination with other forms of high-powered incentives.
} 
we control for audit team maximum tenure - the most years that any member of the audit team had worked at the auditing firm — for the prior and focal audits. We also control for audit sequence by including a series of dummies denoting the supplier's first audit in the sample, the second, and so on, because suppliers may face increasing remediation costs and difficulties in subsequent audits.

\section{Supplier-level Control Variables}

We control for supplier's size because larger factories, being more visible, are exposed to higher regulatory pressures (Surroca et al. 2013), which could increase their willingness to improve. We measure supplier's size as the number of employees, obtained from the auditing company, which we log to reduce skew. We also control for supplier's age because organizational practices have been shown to vary over an organization's life cycle (Hannan and Freeman 1984). We calculate the supplier's age by adding 1 to the difference between the audit year and the factory's founding year. We top-code the values at the 99th percentile of the sample distribution (68) to reduce the potential impact of outliers, then use the log to reduce skew.

We control for several other factors that might influence a supplier's improvement rate. Research shows that migrant workers are more likely to be exploited and mistreated while local workers tend to demand better working conditions (Flanagan 2006). Managers in factories with a higher proportion of local workers (compared to migrant workers) might therefore face more pressure to improve working conditions. In contrast, some factories might invest in improving working conditions to better attract migrant workers. These competing concerns lead us to control for local worker ratio in the supplier factory, operationalized as the percentage of frontline employees who are local, based on audit data. Gender differences in the workforce might also influence improvement rates. Research shows that female employees' complaints about working conditions are disregarded by their supervisors (Breslin et al. 2007). Thus, a workplace with more female employees might improve less. In contrast, research also shows that male employees often stifle their complaints in order to appear masculine (Breslin et al. 2007). These competing concerns lead us to control for female worker ratio in the supplier factory, operationalized as the percentage of frontline employees who are women. Furthermore, some 
factories outsource part of their production to subcontractors to evade health and safety requirements (Society for Labor and Development et al. 2015). Because factories that subcontract might improve more if they outsource problems, we include a dummy variable use subcontractors, which we code based on audit data.

\section{Country-level Control Variables}

Following prior research (Antràs and Chor 2013, Locke et al. 2007), we control for rule of law — that is, for a country's legal and regulatory environment—using the Rule of Law Index from the World Bank's Worldwide Governance Indicators, which “captur[es] perceptions of the extent to which agents have confidence in and abide by the rules of society, and in particular the quality of contract enforcement, property rights, the police, and the courts, as well as the likelihood of crime and violence" (Kaufmann et al. 2011: 3). Prior research indicates that the level of press freedom in a supplier's country can influence the improvement of its working conditions by affecting the risk that poor conditions will be exposed and sanctioned (Hugill et al. 2016). We measure press freedom as the Press Freedom Index from Reporters without Borders, which we reverse-code so that higher values indicate greater press freedom and rescale to range from 0 to 1. Lastly, we control for a supplier country's dependence on foreign direct investment (FDI) because it might influence the international pressure on suppliers to improve their practices and meet international labor standards (Toffel et al. 2015). Using World Bank data, we operationalize this by calculating the percentage of FDI in each supplier country's gross domestic product in the year of the prior audit, FDI inflow, and logging the result to reduce skew.

\section{ESTIMATION AND RESULTS}

The aforementioned independent variables and control variables can influence working condition scores in both the prior and focal audits. Therefore, to predict improvement, we need to account for these factors for both audits. We include audit team characteristics - gender composition, average age, and maximum tenure — for both the prior and focal audits. ${ }^{7}$ However, because the supplier-

\footnotetext{
${ }^{7}$ About $10 \%$ of the suppliers in our sample report information about the presence of a workers' union, piece-rate payment, or certification that is inconsistent between the prior and focal audits. Since we cannot tell whether a
} 
and country-level variables are very stable, including them for both audits would substantially increase multicollinearity without adding meaningful controls. ${ }^{8}$ Therefore, we include the values of supplier- and country-level variables for the prior audit but not for the focal audit.

We also include industry fixed effects and year fixed effects to control for potential differences in improvement rate between suppliers in different industries and between various years in our sample. Because research shows that buyers' headquarters country-level governmental, economic, and civil society attributes can influence their attentiveness to supply chain conditions, which can in turn affect how much pressure they exert on their suppliers to comply to labor standards (Toffel et al. 2015), we construct dummy variables for each buyer's headquarters country. Furthermore, we also include supplier-country fixed effects to control for unobservable country characteristics that may influence improvement in suppliers' working conditions. ${ }^{9}$

\section{Results}

We test our hypotheses using ordinary least squares (OLS) regression, clustering standard errors by the supplier's country. Descriptive statistics are reported in Table 3, correlations in Table 4, and regression results in Table 5 .

We test Hypothesis 1 with Model 1 in Table 5, which presents estimation results for our directeffect hypotheses. The statistically significant positive coefficient on certification (prior audit) $(\beta=$ $0.95, \mathrm{p}<0.001)$ indicates that certified suppliers improve more than noncertified suppliers, which supports H1. Predictive margins indicate that noncertified suppliers improved by an average of 6.0 points and certified suppliers by 7.0 points, or $17 \%$ more. The statistically significant positive coefficient on workers' union (prior audit) $(\beta=1.17, \mathrm{p}<0.001)$ shows that unionized suppliers improve

given inconsistency is due to a data entry error or to an actual change - for example, if the factory unionized between one audit and the next-we dropped these suppliers from our sample. (Including these suppliers in the sample, as a robustness test, yielded nearly identical results.)

${ }^{8}$ For instance, the correlation of supplier's size between the prior and focal audits is 0.96 and the correlation of female worker ratio between the prior and focal audits is 0.86 .

${ }^{9}$ Because our model includes supplier-country fixed effects, also including the supplier-country-level variables rule of law, press freedom, and FDI inflows risks introducing multicollinearity. We therefore also estimated our models without these three variables, which yielded nearly identical results. 
more than non-unionized suppliers, which supports H2. Predictive margins indicate that non-unionized suppliers improved by 5.9 points and union suppliers improved by 7.1 points, or $20 \%$ more.

We test Hypothesis 3 with Model 2, which adds the interaction term workers' union (prior audit) $\times$ certifications (prior audit) and yields a statistically significant positive coefficient $(\beta=2.88, \mathrm{p}<0.01)$. Predictive margins indicate that certified factories that were unionized improved by 9.1 points, whereas certified factories that were not unionized improved by 5.7 points, or $37 \%$ less. This difference is statistically significant, based on a Wald test comparing the coefficient on the interaction term to the coefficient on certification (prior audit) (Wald $\mathrm{F}=5.88, \mathrm{p}<0.05$ ). This supports $\mathrm{H} 3$.

To test Hypothesis 4, we return to Model 1. The statistically significant negative coefficient on piece-rate payment (prior audit) $(\beta=-3.38, \mathrm{p}<0.001)$ reveals that factories paying workers on a piecerate basis tend to improve less than other factories, which supports H4. Predictive margins indicate that suppliers that did not use piece-rate payment improved by 6.6 points, whereas those that did improved by 3 points, or less than half as much.

We test Hypothesis 5a with Model 3, which adds the interaction term piece-rate payment (prior audit) $\times$ certification (prior audit). The model yields a marginally significant positive coefficient on this interaction term $(\beta=1.06, \mathrm{p}<0.10)$, which indicates that the negative relationship between productivity incentives and improvement in working conditions is attenuated for certified factories. This provides some support for H5a. Predictive margins indicate that for noncertified factories, improvement averaged 6.5 points for those that did not use piece-rate payment and 2.6 points, or $60 \%$ less, for those that did. In contrast, for certified factories, improvement averaged 7.3 points for those that did not use piece-rate payment and 4.5 , or only $38 \%$ less, for those that did. The significant coefficient on the interaction term confirms that the latter difference is significantly smaller than the former. Figure 1 in Appendix A graphs these average predicted effects along with their $95 \%$ confidence intervals.

We test Hypothesis $5 \mathrm{~b}$ with Model 4, which adds the interaction term piece-rate payment (prior audit) $\times$ workers' union (prior audit). The model yields a statistically significant positive coefficient on 
this interaction term $(\beta=1.12, \mathrm{p}<0.05)$, which indicates that the negative relationship between productivity incentives and improvement in working conditions is attenuated for unionized factories. This supports H5b. Predictive margins indicate that for non-unionized factories, improvement averaged 6.3 points for those that did not use piece-rate payment and 2.3 points, or $63 \%$ less, for those that did. In contrast, for unionized factories, improvement averaged 7.3 points for those that did not use piece-rate payment and 4.4 , or only $40 \%$ less, for those that did. The significant coefficient on the interaction term confirms that the latter difference is significantly smaller than the former difference. Figure 2 in Appendix A graphs these average predicted effects.

\section{Robustness Tests}

We conduct further analysis to assess the extent to which our results are robust to two potentially important missing variables. First, research suggests that whether the audit is announced or unannounced can influence the rate at which supplier working conditions improve (Hugill et al. 2016). We estimate a model that included two dummy variables, announced (prior audit) and announced (focal audit), coded 1 if the audit was announced and 0 if it was unannounced. This model yields coefficients, magnitudes, and standard errors very similar to those of the model without these two dummy variables. Second, the amount of improvement suppliers experience might depend on the amount of time between their prior and focal audits. To assess whether the time gap influenced our results, we construct a new dependent variable, improvement per month, by dividing improvement by the number of months between the prior and focal audits. Estimating our primary models on this new dependent variable continued to yield statistically significant coefficients of the same sign on most hypothesized effects, except for the coefficient of the interaction term piece-rate payment (prior audit) $\times$ certification (prior audit). We describe these robustness tests in more detail in Appendix B, where we also report results in Tables B1 and B2.

\section{Supplemental Analysis: Prescriptive versus Generative Management Systems}

In the above analyses, we treat management system standards certification generically, focusing on the process improvement features common to these regimes. However, certain types of management 
system standards might be more likely than others to be associated with improvement in working conditions. In this section, we conduct supplemental analyses to investigate whether certifications differ in this regard depending on their relative emphasis on the continuous development of objectives and management systems versus on compliance with substantive, externally prescribed rules.

Several of the certification programs in our sample prescribe substantive rules with which suppliers must comply to obtain certification. For example, the Business Social Compliance Initiative (BSCI) management system standard includes a code of conduct requiring fair remuneration and observance of specified occupational health and safety rules and prohibiting child labor and forced labor. Worldwide Responsible Accredited Production (WRAP) mandates that suppliers adhere to twelve "Production Principles" similarly protecting workers' rights. These management systems provide a set of externally imposed prescriptive rules and the demand for straightforward compliance verification. We define these as "prescriptive" certifications and code the variable prescriptive certification (prior audit) as 1 when the audited supplier has been certified to one of them and 0 otherwise.

In contrast, we define "generative" certifications as those which lack prescriptive rules and instead require the organization to identify and develop its own objectives based on risk assessment practices and to update these objectives over time through processes of periodic review and continuous learning. For instance, ISO 9001 places responsibility on the certified organization to "establish the objectives and processes necessary to deliver results" (ISO 9001-2000: vi) and ISO 14001 stresses that objectives may differ across organizations (ISO14001-1996). We code the variable generative certification (prior audit) as 1 when the audited supplier is certified to one of these systems and 0 otherwise. (Table $\mathrm{C} 1$ in Appendix $\mathrm{C}$ lists the prescriptive and generative certifications in our sample.) Replacing our single certification variable with these two certification variables yields a positive and significant coefficient on generative certification (prior audit) and a nonsignificant coefficient on prescriptive certification (prior audit). (Results are reported as Model 1 in Table C2 in the Appendix C.) These results indicate that generative certification is associated with more improvement, but they offer no evidence that prescriptive certification is. Specifically, suppliers with generative certification 
improved an average of 7.1 points, $16 \%$ more than the average 6.1 -point improvement among those that lacked any certification. We speculate that being certified to a generative standard requires continuous updates of objectives, which are associated with more dynamic inputs and more self-reflection. In contrast, being certified to a prescriptive standard requires meeting a static set of objectives. Such programs are often used as a "seal of approval" to market good practices to reputation-sensitive global buyers, but not necessarily to substantially improve those practices.

\section{DISCUSSION}

Our study reveals important insights about the relationship between organizational practices and formal organizational structures adopted in response to legitimacy demands in environments imposing onerous efficiency imperatives. First, both legalization (certified management systems) and worker participation (unionization) structures are associated with greater improvement in suppliers' working conditions. We also find support for the argument that worker participation enhances the positive association between legalization structures and improvement. Second, suppliers that have instituted productivity incentive structures exhibit less improvement in working conditions. Moreover, we identify important dependencies between these organizational structures: both management system certification and unions attenuate the negative relationship between productivity incentives and improvement in working conditions. These findings contribute in several important ways to theory and practice.

\section{Contribution to the Literature on Formal Organizational Structures and Practices}

First, we demonstrate variations in the coupling of certain legitimacy-related organizational structures in less-elaborated institutional environments. This finding alone is an important contribution, given the literature's current theoretical orientation toward the coupling power of coercive state pressures and civil society pressures. This orientation has motivated recent studies finding such gaps between companies' adoption of international human rights commitments and their implementation of those commitments to such an extent that some studies have not even entertained the possibility that corporate commitments could be substantive rather than symbolic (Berliner and Prakash 2015, Lim and 
Tsutsui 2012). Lim and Tsutsui (2012), for instance, confine their inquiry to whether membership in the UN Global Compact is merely symbolic or utterly cynical—adopted "to cover, or bluewash, [corporations'] socially irresponsible practices" (Lim and Tsutsui 2012: 72) — never considering how the organizational structures and practices attendant to Global Compact participation might actually shape corporate behaviors. Our study, however, finds that even in emerging economies — where labor regulatory institutions are weak and efficiency demands are strong-both certification and unionization can become sufficiently coupled in supplier organizations to attenuate the negative association between productivity incentives and improvement in working conditions. This suggests the need to reconsider the boundary conditions delineating environments in which coupling is more or less likely to occur.

Second, our focus on the internal structural dynamics of organizations to ascertain how coupling varies across firms in unpromising institutional environments significantly extends a body of scholarship that has concentrated largely on the coupling force of institutional factors external to organizations (e.g., Bartley and Egels-Zandén 2016, Bromley and Powell 2012, Hafner-Burton and Tsutsui 2005). In addition, our attention to the complex and contingent relationships among organizational structures extends research on internal coupling processes which, to date, has centered on the activities and interactions of individual organizational actors, such as powerful managers (Fiss and Zajac 2004, Hallett 2010, Overdevest 2010), a new generation of differently trained personnel (Tilcsik 2010), or boundaryspanning professionals (Edelman 1992, Sutton and Dobbin 1996). We add to this literature by demonstrating the dynamic interaction of multiple and potentially competing internal structures. Specifically, worker participation structures enhance legalization structures and both structures attenuate the negative association between productivity incentive structures and improvement in working conditions. This type of analysis is crucial to understanding organizational coupling processes in a world in which organizations are subject to complex demands which they often address through multiple and competing formal organizational structures.

Third, we identify organizational learning as the key mechanism characterizing formal organizational structures associated with improved organizational practices, bringing it back to the 
forefront of coupling conversations that have been dominated by other factors. Specifically, we argue that both legalization and worker participation structures either drive or reflect effective learning processes in supplier organizations and that these processes expedite organizational improvement. Our supplementary analysis further suggests the importance of organizational learning to coupling. We found no statistically significant improvement among suppliers certified to prescriptive management systems, which mandate substantive outcomes and grant suppliers a "seal of approval" for meeting these static targets. Instead, our finding that certification is associated with greater improvement turns out to be driven entirely by generative management systems, which emphasize organizational learning and continuous improvement processes without prescribing specific substantive outcomes. These findings contribute to the handful of studies that have investigated whether certification to management systems standards in one domain — for instance, environmental compliance or quality control—can improve management practices in ways that spill over into other domains (e.g., King et al. 2005, Levine and Toffel 2010).

Fourth, our work shifts the focus of research on coupling from levels of organizational practices measured at a single point in time (static) to improvements in organizational practices over time (dynamic). Most coupling and decoupling studies have measured static levels of organizational performance to assess the gap between structure and practice. But legitimacy-oriented structures are typically adopted in response to demands for organizational change. Consequently, it is crucial to understand the association between these structures and changes in organizational practices to better understand if coupling has occurred.

\section{Contribution to the Literature on Working Conditions in Global Supply Chains}

First, our study suggests that attending to the behavior of suppliers is important for research on global value chains and on the more commonly studied MNCs at the center of these production networks. For instance, studies documenting "bluewashing” (Berliner and Prakash 2015, Lim and Tsutsui 2012) by Global Compact members focus on the behavior of global MNC buyers and not of their suppliers up the value chain. Yet those suppliers are subject to very different efficiency and 
legitimacy imperatives as well as to monitoring demands imposed by global buyers, forces that may shape their behavior differently than those that shape MNC behavior. It may be shortsighted to dismiss private governance initiatives by MNCs as "bluewashing" if they have measurable effects on the behavior of suppliers.

Second, our extension, which failed to find an association between prescriptive certification regimes and improvement in working conditions, raises important questions about when "bluewashing" is likely to occur. Suppliers in our sample certified under prescriptive certification programs showed no more propensity to improve their labor standards than other suppliers, even though their working conditions were no better than those of other suppliers at the time of certification. By contrast, suppliers enrolled in generative management system certification regimes (such as ISO) - that instead focus on shaping internal organizational systems - improved more rapidly than other suppliers. This suggests the need for caution in assessing the value of certification and nuance in understanding the design and function of different management certification systems when theorizing and testing their effects. In other words, not all organizational structures are created equal and it is important to understand the variation in their design and mechanisms when theorizing their relationship to organizational practices.

For practitioners, our findings provide important insights for MNCs selecting supplier factories and design governance regimes to improve working conditions. Many MNCs have focused on cultivating long-term relationships with suppliers and helping these partners improve their working conditions. Our findings suggest that MNCs can strategically target suppliers that have deployed legalization and worker participation mechanisms while being wary of suppliers using piece-rate payment. Furthermore, because of the centrality of economic incentives in influencing working conditions, altering the internal payment structure from piece-rate to hourly may help. For suppliers that cannot change their payment schemes systemically in the near term, instituting alternative governance structures, including worker participation and certification programs, can at least reduce the negative influence of productivity incentives. 


\section{Limitations and Future Directions}

First, we stress that our study cannot test causality. For our direct-effect hypotheses (H1, H2, and H4), our dataset does not enable us to empirically disentangle "signaling" mechanisms from “coupling" mechanisms. On the one hand, organizational structures like certified management systems and worker participation mechanisms might drive improvement in working conditions. On the other hand, these governance structures might be credible signals of "good" suppliers that have the willingness and capacity to improve their performance. Although the implications of either mechanism are similar for MNC managers seeking to know which suppliers are more likely to improve their working conditions, the further development of decoupling theory requires the disentangling of these mechanisms. We encourage future researchers to find buyers and auditors willing to conduct field experiments to tease out the "signaling" and "coupling" effects of organizational governance structures.

Second, our dataset lacks data on supplier profitability and management characteristics and on buyer-supplier order history and contractual terms, all of which might influence suppliers' improvement rates. We encourage future research to consider the possible effects of these factors on improvement in working conditions in order to further unpack the relationship between organizational governance structures and changes in organizational practices.

Third, we rely on a single auditing company and measure labor standards only by supplier factories' compliance with codes of conduct assessed by this company. Researchers should use caution when applying our findings to factories that do not serve global buyers. Furthermore, auditing reports can only reflect part of the reality of suppliers' working conditions. Researchers and other stakeholders should be aware of the limitations of audit reports.

\section{CONCLUSION}

Many skeptics have argued that organizational governance structures are not associated with actual changes in organizational practices. Our findings suggest that there is a positive association such that even in the context of global supply chains, in which economic efficiency demands dominate, 
suppliers that institute legalization (certified management system standards) and worker participation structures (unions) show greater improvement in their working conditions. Moreover, we find evidence that these governance structures can temper some of the negative effects that efficiency demands have on social compliance. Our findings call for the need to look beyond the symbolism of organizational structures and attend to how they can be associated with actual implementation and improvement.

\section{REFERENCES}

Ang D, Brown D, Dehejia R, Robertson R (2012) Public disclosure, reputation sensitivity, and labor law compliance: Evidence from Better Factories Cambodia. Rev. Dev. Econ. 16(4):594-607.

Anner M (2012) Corporate Social Responsibility and Freedom of Association Rights The Precarious Quest for Legitimacy and Control in Global Supply Chains. Polit. Soc. 40(4):609-644.

Anner M, Bair J, Blasi J (2013) Towards Joint Liability in Global Supply Chains: Addressing the Root Causes of Labor Violations in International Subcontracting Networks. Comp. Labor Law Policy J. 35(1):1-43.

Anner M, Liu X (2016) Harmonious Unions and Rebellious Workers A Study of Wildcat Strikes in Vietnam. ILR Rev. 69(1):3-28.

Antràs P, Chor D (2013) Organizing the Global Value Chain. Econometrica 81(6):2127-2204.

Appelbaum E (2000) Manufacturing Advantage: Why High-Performance Work Systems Pay Off (Cornell University Press, Ithaca, N.Y.).

Ayres I, Braithwaite J (1992) Responsive Regulation: Transcending the Deregulation Debate. (Oxford University Press, Incorporated, Cary).

Bartley T (2005) Corporate accountability and the privatization of labor standards: Struggles over codes of conduct in the apparel industry. Res. Polit. Sociol. 14:211-44.

Bartley T (2011) Certification as a mode of social regulation. Levi-Faur D, ed. Handb. Polit. Regul. (Cheltenham, UK), 441-452.

Bartley T, Egels-Zandén N (2016) Beyond decoupling: unions and the leveraging of corporate social responsibility in Indonesia. Socio-Econ. Rev. 14(2):231-255.

Bender KA, Sloane PJ (1999) Trade union membership, tenure and the level of job insecurity. Appl. Econ. 31(1):123-135.

Berliner D, Prakash A (2015) "Bluewashing” the firm? Voluntary regulations, program design, and member compliance with the United Nations Global Compact. Policy Stud. J. 43(1):115-138.

Boiral O (2007) Corporate Greening through ISO 14001: A Rational Myth? Organ. Sci. 18(1):127-146.

Breslin C, Polzer J, MacEachen E, Morrongiello B, Shannon H (2007) Workplace injury or "part of the job"?: Towards a gendered understanding of injuries and complaints among young workers. Soc. Sci. Med. 64(4):782-793.

Bromley P, Powell WW (2012) From Smoke and Mirrors to Walking the Talk: Decoupling in the Contemporary World. Acad. Manag. Ann. 6(1):483-530.

Brown GD, O'Rourke D (2007) Lean Manufacturing Comes to China: A Case Study of Its Impact on Workplace Health and Safety. Int. J. Occup. Environ. Health 13(3):249-257.

Burawoy M (1983) Between the Labor Process and the State: The Changing Face of Factory Regimes under Advanced Capitalism. Am. Sociol. Rev. 48(5):587-605.

Cafaggi F (2012) Enforcement of transnational regulation: ensuring compliance in a global world (Edward Elgar, Cheltenham, UK; Northampton, MA).

Chen M shia, Chan A (2004) Employee and union inputs into occupational health and safety measures in Chinese factories. Soc. Sci. Med. 58(7):1231-1245. 
Christensen LT, Morsing M, Thyssen O (2013) CSR as aspirational talk. Organization 20(3):372-393.

Council on Economic Priorities Accreditation Agency (1999) Guidance document for social accountability 8000 .

Crossan MM, Lane HW, White RE (1999) An Organizational Learning Framework: From Intuition to Institution. Acad. Manage. Rev. 24(3):522-537.

Cyert RM, March JG (1963) A behavioral theory of the firm (Prentice-Hall, Engelwood).

Distelhorst G, Hainmueller J, Locke RM (2016) Does Lean Improve Labor Standards? Management and Social Performance in the Nike Supply Chain. Manag. Sci. 63(3):707-728.

Dobbin F, Kelly EL (2007) How to Stop Harassment: Professional Construction of Legal Compliance in Organizations. Am. J. Sociol. 112(4):1203-1243.

Dobbin F, Sutton JR (1998) The Strength of a Weak State: The Rights Revolution and the Rise of Human Resources Management Divisions. Am. J. Sociol. 104(2):441-476.

Dohmen T, Falk A (2011) Performance Pay and Multidimensional Sorting: Productivity, Preferences, and Gender. Am. Econ. Rev. 101(2):556-590.

Dong X, Entzel P, Men Y, Chowdhury R, Schneider S (2004) Effects of safety and health training on work-related injury among construction laborers. J. Occup. Environ. Med. 46(12):1222-1228.

Dunlop JT, Weil D (1996) Diffusion and Performance of Modular Production in the U.S. Apparel Industry. Ind. Relat. J. Econ. Soc. 35(3):334-355.

Edelman LB (1992) Legal Ambiguity and Symbolic Structures: Organizational Mediation of Civil Rights Law. Am. J. Sociol. 97(6):1531-1576.

Egels-Zandén N (2007) Suppliers' Compliance with MNCs' Codes of Conduct: Behind the Scenes at Chinese Toy Suppliers. J. Bus. Ethics 75(1):45-62.

Fiol CM, Lyles MA (1985) Organizational Learning. Acad. Manage. Rev. 10(4):803-813.

Fiss PC, Zajac EJ (2004) The Diffusion of Ideas over Contested Terrain: The (Non)adoption of a Shareholder Value Orientation among German Firms. Adm. Sci. Q. 49(4):501-534.

Flanagan RJ (2006) Globalization and labor conditions: working conditions and worker rights in a global economy (Oxford University Press, Oxford, UK; New York).

Fransen L (2012) Multi-stakeholder governance and voluntary programme interactions: legitimation politics in the institutional design of Corporate Social Responsibility. Socio-Econ. Rev. 10(1):163-192.

Freeman RB (1980) The Exit-Voice Tradeoff in the Labor Market: Unionism, Job Tenure, Quits, and Separations. Q. J. Econ. 94(4):643-673.

Friedman E, Lee CK (2010) Remaking the World of Chinese Labour: A 30-Year Retrospective. Br. J. Ind. Relat. 48(3):507-533.

Gereffi G, Christian M (2009) The Impacts of Wal-Mart: The Rise and Consequences of the World's Dominant Retailer. Annu. Rev. Sociol. 35(1):573-591.

Gereffi G, Humphrey J, Sturgeon T (2005) The governance of global value chains. Rev. Int. Polit. Econ. 12(1):78-104.

Gillen M, Baltz D, Gassel M, Kirsch L, Vaccaro D (2002) Perceived safety climate, job demands, and coworker support among union and nonunion injured construction workers. J. Safety Res. 33(1):33-51.

Hafner-Burton EM, Tsutsui K (2005) Human Rights in a Globalizing World: The Paradox of Empty Promises. Am. J. Sociol. 110(5):1373-1411.

Hallett T (2010) The Myth Incarnate Recoupling Processes, Turmoil, and Inhabited Institutions in an Urban Elementary School. Am. Sociol. Rev. 75(1):52-74.

Hannan MT, Freeman J (1984) Structural Inertia and Organizational Change. Am. Sociol. Rev. 49(2):149-164.

Heywood JS, Wei X (1997) Piece-Rate Payment Schemes and the Employment of Women: The Case of Hong Kong. J. Comp. Econ. 25(2):237-255.

Holmstrom B, Milgrom P (1991) Multitask Principal-Agent Analyses: Incentive Contracts, Asset Ownership, and Job Design. J. Law Econ. Organ. 7(Special Issue):24-52. 
Holweg M (2007) The genealogy of lean production. J. Oper. Manag. 25(2):420-437.

Hugill A, Short JL, Toffel MW (2016) Beyond Symbolic Responses to Private Politics: Examining Labor Standards Improvement in Global Supply Chains. Work. Pap. (17-1).

Inditex (2017) Framework Agreement with IndustriALL. Retrieved (May 16, 2017), http://www.inditex.com/en/sustainability/suppliers/code_conduct\#panel_1.

International Organization for Standardization (2000) ISO 9001 Quality Mangement Systems Requirements.

Kaufmann D, Kraay A, Mastruzzi M (2011) The worldwide governance indicators: methodology and analytical issues. Hague J. Rule Law 3(2):220-246.

King AA, Lenox MJ, Terlaak A (2005) The Strategic Use of Decentralized Institutions: Exploring Certification With the ISO 14001 Management Standard. Acad. Manage. J. 48(6):1091-1106.

Lazear EP (2000) The Power of Incentives. Am. Econ. Rev. 90(2):410-414.

Levine DI, Toffel MW (2010) Quality Management and Job Quality: How the ISO 9001 Standard for Quality Management Systems Affects Employees and Employers. Manag. Sci. 56(6):978-996.

Lilley R, Feyer AM, Kirk P, Gander P (2002) A survey of forest workers in New Zealand: Do hours of work, rest, and recovery play a role in accidents and injury? J. Safety Res. 33(1):53-71.

Lim A, Tsutsui K (2012) Globalization and Commitment in Corporate Social Responsibility: CrossNational Analyses of Institutional and Political-Economy Effects. Am. Sociol. Rev. 77(1):69-98.

Locke R, Amengual M, Mangla A (2009) Virtue Out of Necessity? Compliance, Commitment, and the Improvement of Labor Conditions in Global Supply Chains. Polit. Soc. 37(3):319-351.

Locke RM (2013) The promise and limits of private power: promoting labor standards in a global economy (Cambridge University Press, Cambridge, UK).

Locke RM, Qin F, Brause A (2007) Does monitoring improve labor standards? Lessons from Nike. Ind. Labor Relat. Rev. 61(1):3-31.

Locke RM, Rissing BA, Pal T (2013) Complements or Substitutes? Private Codes, State Regulation and the Enforcement of Labour Standards in Global Supply Chains. Br. J. Ind. Relat. 51(3):519-552.

Marquis C, Qian C (2014) Corporate Social Responsibility Reporting in China: Symbol or Substance? Organ. Sci. 25(1):127-148.

Marquis C, Toffel M, Zhou Y (2016) Scrutiny, Norms, and Selective Disclosure: A Global Study of Greenwashing. Organ. Sci. 27(2):483-504.

Meng R, Smith D (1993) Union Impacts on the Receipt of Workers' Compensation Benefits. Relat. Ind. Ind. Relat. 48(3):503-518.

Meyer JW, Boli J, Thomas GM, Ramirez FO (1997) World society and the nation-state. Am. J. Sociol. 103(1):144-181.

Meyer JW, Rowan B (1977) Institutionalized Organizations: formal structure as myth and ceremony. Am. J. Sociol. 83(2):340-363.

Morantz A (2015) The elusive union safety effect: toward a new empirical research agenda. Memb.Libr.

Morse T, Punnett L, Warren N, Dillon C, Warren A (2003) The relationship of unions to prevalence and claim filing for work-related upper-extremity musculoskeletal disorders. Am. J. Ind. Med. 44(1):83-93.

Nadvi K, LunD-Thomsen P, Xue H, Khara N (2011) Playing against China: global value chains and labour standards in the international sports goods industry. Glob. Netw. 11(3):334-354.

Nissen B, Angee A, Weinstein M (2008) Immigrant Construction Workers and Health and Safety The South Florida Experience. Labor Stud. J. 33(1):48-62.

Okhmatovskiy I, David RJ (2011) Setting Your Own Standards: Internal Corporate Governance Codes as a Response to Institutional Pressure. Organ. Sci. 23(1):155-176.

O’Rourke D (2003) Outsourcing Regulation: Analyzing Nongovernmental Systems of Labor Standards and Monitoring. Policy Stud. J. 31(1):1-29.

Overdevest C (2010) Comparing forest certification schemes: the case of ratcheting standards in the forest sector. Socio-Econ. Rev. 8(1):47-76. 
Parker C (2002) The open corporation: effective self-regulation and democracy (Cambridge University Press, New York).

Patterson PB (2007) Attributions of danger and responses to risk among logging contractors in British Columbia's Southern interior: implications for accident prevention in the forest industry. Res. Econ. Anthropol. 26:103-125.

Prendergast C (1999) The Provision of Incentives in Firms. J. Econ. Lit. 37(1):7-63.

Rees JV (1988) Reforming the workplace: a study of self-regulation in occupational safety (University of Pennsylvania Press, Philadelphia).

Reilly B, Paci P, Holl P (1995) Unions, Safety Committees and Workplace Injuries. Br. J. Ind. Relat. 33(2):275-288.

Rodriguez-Garavito CA (2005) Global Governance and Labor Rights: Codes of Conduct and AntiSweatshop Struggles in Global Apparel Factories in Mexico and Guatemala. Polit. Soc. 33(2):203-333.

Seidman G (2007) Beyond the boycott: labor rights, human rights, and transnational activism (Russell Sage Foundation, New York).

Selznick P (1992) The moral Commonwealth: social theory and the promise of community. (University of California Press, Berkeley).

Selznick P, Nonet P, Vollmer HM, Russell Sage Foundation (1969) Law, society, and industrial justice (Russell Sage Foundation, New York).

Shea A, Nakayama M, Heymann J (2010) Improving Labour Standards in Clothing Factories: Lessons from Stakeholder Views and Monitoring Results in Cambodia. Glob. Soc. Policy 10(1):85-110.

Short JL, Toffel MW (2010) Making Self-Regulation More Than Merely Symbolic: The Critical Role of the Legal Environment. Adm. Sci. Q. 55(3):361-369.

Short JL, Toffel MW, Hugill AR (2016) Monitoring global supply chains. Strateg. Manag. J. 37:18781897.

Society for Labor and Development, LIPS Sedane, Indonesia, Community Legal Education Center, Cambodia (2015) New Findings on Conditions Across Walmart's Garment Supplier Factories in Cambodia, India, and Indonesia.

Sundstroem-Frisk C (1984) Behavioural control through piece-rate wages. J. Occup. Accid. 6(1):49-59.

Surroca J, Tribó JA, Zahra SA (2013) Stakeholder Pressure on MNEs and the Transfer of Socially Irresponsible Practices to Subsidiaries. Acad. Manage. J. 56(2):549-572.

Sutton JR, Dobbin F (1996) The Two Faces of Governance: Responses to Legal Uncertainty in U.S. Firms, 1955 to 1985. Am. Sociol. Rev. 61(5):794-811.

Teubner G (1983) Substantive and reflexive elements in modern law. Law Soc. Rev.:239-285.

Tilcsik A (2010) From Ritual to Reality: Demography, Ideology, and Decoupling in a Post-Communist Government Agency. Acad. Manage. J. 53(6):1474-1498.

Toffel MW, Short JL, Ouellet M (2015) Codes in context: How states, markets, and civil society shape adherence to global labor standards. Regul. Gov. 9(3):205-223.

Vinodkumar MN, Bhasi M (2011) A study on the impact of management system certification on safety management. Saf. Sci. 49(3):498-507.

Walters D (2006) One step forward, two steps back: worker representation and health and safety in the United Kingdom. Int. J. Health Serv. 36(1):87-111.

Weyman A, D. Clarke D, Cox T (2003) Developing a factor model of coal miners' attributions on risktaking at work. Work Stress 17(4):306-320.

Williamson OE (1985) The economic institutions of capitalism: firms, markets, relational contracting (Free Press ; Collier Macmillan, New York; London).

Yang H, Phelps C, Steensma HK (2010) Learning from What Others Have Learned from You: The Effects of Knowledge Spillovers on Originating Firms. Acad. Manage. J. 53(2):371-389.

Yu X (2009) From Passive Beneficiary to Active Stakeholder: Workers' Participation in CSR Movement Against Labor Abuses. J. Bus. Ethics 87(1):233. 
Table 1. Industry Composition of Audits and Audited Suppliers

\begin{tabular}{|l|rr|cr|}
\hline & \multicolumn{2}{|c|}{ Audits } & \multicolumn{2}{c|}{ Suppliers } \\
\hline Industry & Number & Percent & Number & Percent \\
\hline Hardlines & 968 & $19.8 \%$ & 631 & $19.3 \%$ \\
Apparel & 899 & $18.4 \%$ & 614 & $18.7 \%$ \\
Electronics & 414 & $8.5 \%$ & 277 & $8.5 \%$ \\
Housewares & 334 & $6.8 \%$ & 214 & $6.5 \%$ \\
Textiles & 329 & $6.7 \%$ & 235 & $7.2 \%$ \\
Toys & 328 & $6.7 \%$ & 222 & $6.8 \%$ \\
Food & 224 & $4.6 \%$ & 140 & $4.3 \%$ \\
Accessories & 227 & $4.6 \%$ & 170 & $5.2 \%$ \\
Personal Use Items & 195 & $4.0 \%$ & 141 & $4.3 \%$ \\
Footwear & 157 & $3.2 \%$ & 106 & $3.2 \%$ \\
Automotive & 117 & $2.4 \%$ & 70 & $2.1 \%$ \\
Sports Equipment & 110 & $2.3 \%$ & 71 & $2.2 \%$ \\
Leather Goods & 104 & $2.1 \%$ & 80 & $2.4 \%$ \\
Paper Products & 88 & $1.8 \%$ & 63 & $1.9 \%$ \\
Bottling & 69 & $1.4 \%$ & 42 & $1.3 \%$ \\
Technical & 28 & $0.6 \%$ & 22 & $0.7 \%$ \\
Other & 296 & $6.1 \%$ & 178 & $5.4 \%$ \\
\hline Total & 4,887 & $100 \%$ & 3,276 & $100 \%$ \\
\hline
\end{tabular}

Table 2. Location of Audits and Audited Suppliers

\begin{tabular}{|l|rr|rr|}
\hline & \multicolumn{2}{|c|}{ Audits } & \multicolumn{2}{c|}{ Suppliers } \\
\hline Location of audits & Number & Percent & Number & Percent \\
\hline China & 3,732 & $76.4 \%$ & 2,456 & $77.0 \%$ \\
India & 174 & $3.6 \%$ & 129 & $3.9 \%$ \\
Cambodia & 136 & $2.8 \%$ & 77 & $2.4 \%$ \\
Vietnam & 128 & $2.6 \%$ & 93 & $2.8 \%$ \\
Indonesia & 108 & $2.2 \%$ & 61 & $1.9 \%$ \\
Taiwan & 90 & $1.8 \%$ & 66 & $2.0 \%$ \\
Italy & 88 & $1.8 \%$ & 71 & $2.2 \%$ \\
Thailand & 85 & $1.7 \%$ & 57 & $1.7 \%$ \\
South Korea & 52 & $1.1 \%$ & 34 & $1.0 \%$ \\
Turkey & 36 & $0.7 \%$ & 27 & $0.8 \%$ \\
Mexico & 35 & $0.7 \%$ & 30 & $0.9 \%$ \\
Sri Lanka & 20 & $0.4 \%$ & 10 & $0.3 \%$ \\
Bangladesh & 16 & $0.3 \%$ & 13 & $0.4 \%$ \\
Egypt & 16 & $0.3 \%$ & 11 & $0.3 \%$ \\
Guatemala & 15 & $0.3 \%$ & 12 & $0.4 \%$ \\
United States & 15 & $0.3 \%$ & 12 & $0.4 \%$ \\
Countries with $<15$ audits in sample & 141 & $2.9 \%$ & 117 & $3.6 \%$ \\
\hline Total & 4,887 & $100 \%$ & 3,276 & $100 \%$ \\
\hline
\end{tabular}


Table 3. Summary Statistics

\begin{tabular}{|c|c|c|c|c|}
\hline & Mean & S.D. & Min & Max \\
\hline Working condition score (focal audit) & 78.83 & 16.19 & 19.22 & 100 \\
\hline Improvement & 6.19 & 16.53 & -62.42 & 66.55 \\
\hline Certification (prior audit) & 0.15 & 0.36 & 0 & 1 \\
\hline Workers' union (prior audit) & 0.26 & 0.44 & 0 & 1 \\
\hline Piece-rate payment (prior audit) & 0.11 & 0.31 & 0 & 1 \\
\hline Working condition score (prior audit) & 72.65 & 17.33 & 16.05 & 100 \\
\hline Rule of law (prior audit) ${ }^{\mathrm{S}}$ & 0 & 1 & -2.30 & 5.94 \\
\hline Press freedom (prior audit) ${ }^{\mathrm{S}}$ & 0 & 1 & -1.03 & 3.46 \\
\hline FDI inflow (prior audit) ${ }^{\mathrm{L}, \mathrm{S}}$ & 0 & 1 & -3.18 & 1.71 \\
\hline Paid by buyer (prior audit) & 0.33 & 0.47 & 0 & 1 \\
\hline Paid by buyer (focal audit) & 0.33 & 0.47 & 0 & 1 \\
\hline All-female team (prior audit) & 0.34 & 0.47 & 0 & 1 \\
\hline All-female team (focal audit) & 0.36 & 0.48 & 0 & 1 \\
\hline Mixed-gender team (prior audit) & 0.14 & 0.35 & 0 & 1 \\
\hline Mixed-gender team (focal audit) & 0.12 & 0.32 & 0 & 1 \\
\hline Audit team average age (prior audit) & 30.80 & 4.89 & 24.70 & 47 \\
\hline Audit team average age (focal audit) & 31.03 & 5.04 & 24.50 & 47 \\
\hline Audit team maximum tenure (prior audit) & 3.82 & 2.70 & 0.69 & 10.48 \\
\hline Audit team maximum tenure (focal audit) & 4 & 2.75 & 0.72 & 10.48 \\
\hline Audit sequence & 2.73 & 1.01 & 2 & 6 \\
\hline Supplier's size (prior audit) ${ }^{\mathrm{L}}$ & 5.21 & 1.30 & 1.79 & 9.62 \\
\hline Supplier's age (prior audit) ${ }^{\mathrm{L}}$ & 2.22 & 0.74 & 0 & 4.22 \\
\hline Female worker ratio (prior audit) & 0.57 & 0.20 & 0 & 1 \\
\hline Local worker ratio (prior audit) & 0.49 & 0.40 & 0 & 1 \\
\hline Use subcontractors (prior audit) & 0.19 & 0.39 & 0 & 1 \\
\hline
\end{tabular}


Table 4. Correlations

\begin{tabular}{|c|c|c|c|c|c|c|c|c|c|c|c|c|c|c|c|c|c|c|c|c|}
\hline & & 1 & 2 & 3 & 4 & 5 & 6 & 7 & 8 & 9 & 10 & 11 & 12 & 13 & 14 & 15 & 16 & 17 & 18 & 19 \\
\hline 1 & Improvement & 1 & & & & & & & & & & & & & & & & & & \\
\hline 2 & Certification (prior audit) & -0.01 & 1 & & & & & & & & & & & & & & & & & \\
\hline 3 & Workers' union (prior audit) & 0.02 & 0.17 & 1 & & & & & & & & & & & & & & & & \\
\hline 4 & Piece-rate payment (prior audit) & 0.02 & 0.05 & 0.12 & 1 & & & & & & & & & & & & & & & \\
\hline 5 & Working condition score (prior audit) & -0.57 & 0.07 & 0.04 & -0.14 & 1 & & & & & & & & & & & & & & \\
\hline 6 & Rule of law (prior audit) ${ }^{\mathrm{S}}$ & -0.01 & 0.06 & -0.07 & -0.08 & 0.15 & 1 & & & & & & & & & & & & & \\
\hline 7 & Press freedom (prior audit) ${ }^{S}$ & 0.01 & 0.04 & 0.00 & -0.06 & 0.23 & 0.63 & 1 & & & & & & & & & & & & \\
\hline 8 & FDI inflow (prior audit) $\mathrm{L}, \mathrm{S}$ & -0.01 & -0.06 & 0.16 & 0.10 & -0.12 & -0.67 & -0.62 & 1 & & & & & & & & & & & \\
\hline 9 & Paid by buyer (prior audit) & 0.00 & -0.03 & 0.01 & -0.03 & 0.07 & -0.12 & 0.01 & 0.07 & 1 & & & & & & & & & & \\
\hline 10 & Paid by buyer (focal audit) & -0.01 & -0.04 & 0.00 & -0.04 & 0.08 & -0.12 & 0.01 & 0.08 & 0.74 & 1 & & & & & & & & & \\
\hline 11 & All-female team (prior audit) & 0.02 & 0.01 & -0.03 & 0.01 & -0.07 & -0.07 & -0.09 & 0.08 & -0.03 & -0.03 & 1 & & & & & & & & \\
\hline 12 & All-female team (focal audit) & 0.03 & 0.00 & -0.01 & 0.02 & -0.06 & -0.07 & -0.09 & 0.07 & -0.02 & -0.02 & 0.19 & 1 & & & & & & & \\
\hline 13 & Mixed-gender team (prior audit) & 0.05 & 0.03 & 0.10 & 0.00 & 0.00 & -0.08 & 0.06 & 0.06 & 0.09 & 0.08 & -0.29 & -0.04 & 1 & & & & & & \\
\hline 14 & Mixed-gender team (focal audit) & -0.12 & 0.03 & 0.11 & 0.02 & 0.10 & -0.07 & 0.06 & 0.08 & 0.04 & 0.07 & -0.06 & -0.27 & 0.24 & 1 & & & & & \\
\hline 15 & Audit team average age (prior audit) & 0.01 & 0.01 & -0.02 & -0.05 & 0.11 & 0.48 & 0.40 & -0.41 & -0.08 & -0.09 & -0.10 & -0.03 & -0.03 & -0.03 & 1 & & & & \\
\hline 16 & Audit team average age (focal audit) & -0.01 & 0.01 & -0.01 & -0.05 & 0.13 & 0.43 & 0.35 & -0.34 & -0.08 & -0.09 & -0.01 & -0.12 & -0.01 & .000 & 0.46 & 1 & & & \\
\hline 17 & Audit team maximum tenure (prior audit) & 0.05 & 0.00 & 0.02 & -0.02 & 0.00 & 0.24 & 0.19 & -0.14 & -0.03 & -0.03 & -0.09 & -0.03 & 0.16 & 0.08 & 0.55 & 0.22 & 1 & & \\
\hline 18 & Audit team maximum tenure (focal audit) & -0.06 & -0.02 & 0.03 & -0.03 & 0.09 & 0.21 & 0.14 & -0.11 & -0.05 & -0.04 & -0.01 & -0.11 & 0.08 & 0.15 & 0.25 & 0.59 & 0.33 & 1 & \\
\hline 19 & Audit sequence & -0.09 & 0.05 & 0.07 & -0.01 & 0.13 & 0.02 & 0.04 & -0.01 & 0.05 & 0.07 & 0.01 & 0.00 & 0.03 & 0.07 & 0.01 & 0.01 & 0.04 & 0.05 & 1 \\
\hline 20 & Supplier's size (prior audit) ${ }^{\mathrm{L}}$ & -0.01 & 0.24 & 0.33 & 0.11 & 0.03 & -0.22 & -0.01 & 0.19 & 0.00 & -0.02 & -0.08 & -0.03 & 0.37 & 0.33 & -0.10 & -0.11 & 0.08 & 0.03 & 0.12 \\
\hline 21 & Supplier's age (prior audit) ${ }^{\mathrm{L}}$ & -0.03 & 0.14 & 0.16 & 0.02 & 0.08 & 0.28 & 0.20 & -0.21 & -0.08 & -0.08 & -0.04 & -0.01 & 0.05 & 0.05 & 0.13 & 0.10 & 0.07 & 0.07 & 0.14 \\
\hline & Female worker ratio (prior audit) & -0.01 & -0.05 & 0.03 & 0.03 & 0.06 & -0.17 & -0.11 & 0.23 & 0.13 & 0.13 & 0.04 & 0.02 & 0.00 & 0.00 & -0.13 & -0.13 & -0.03 & -0.01 & 0.01 \\
\hline & Local worker ratio (prior audit) & 0.03 & 0.03 & 0.13 & 0.01 & 0.11 & 0.23 & 0.53 & -0.26 & 0.11 & 0.09 & -0.03 & -0.05 & 0.00 & 0.00 & 0.14 & 0.13 & 0.04 & 0.03 & -0.01 \\
\hline \multirow{2}{*}{\multicolumn{2}{|c|}{24 Use subcontractors (prior audit) }} & 0.04 & 0.00 & 0.06 & 0.08 & -0.04 & -0.01 & 0.07 & 0.00 & 0.07 & 0.06 & 0.01 & -0.01 & 0.01 & 0.03 & 0.00 & -0.02 & -0.01 & -0.02 & 0.00 \\
\hline & & 20 & 21 & 22 & 23 & 24 & & & & & & & & & & & & & & \\
\hline & Supplier's size (prior audit) ${ }^{\mathrm{L}}$ & 1 & & & & & & & & & & & & & & & & & & \\
\hline & Supplier's age (prior audit) ${ }^{\mathrm{L}}$ & 0.17 & 1 & & & & & & & & & & & & & & & & & \\
\hline & Female worker ratio (prior audit) & -0.02 & -0.07 & 1 & & & & & & & & & & & & & & & & \\
\hline & Local worker ratio (prior audit) & -0.03 & 0.10 & 0.14 & 1 & & & & & & & & & & & & & & & \\
\hline & Use subcontractors (prior audit) & 0.05 & -0.02 & 0.06 & 0.05 & 1 & & & & & & & & & & & & & & \\
\hline
\end{tabular}

$\mathrm{N}=4,887 ;{ }^{\mathrm{S}}$ indicates standardized; ${ }^{\mathrm{L}}$ indicates logged; ${ }^{\mathrm{L}, \mathrm{S}}$ indicates logged, then standardized. 
Table 5. Regression Results

\begin{tabular}{|c|c|c|c|c|}
\hline Dependent variable: Improvement & (1) & (2) & (3) & (4) \\
\hline \multirow[t]{2}{*}{ Certification (prior audit) } & $0.951 * * *$ & -0.221 & $0.804 * * *$ & $0.930 * * *$ \\
\hline & $(0.183)$ & $(0.381)$ & $(0.220)$ & $(0.182)$ \\
\hline \multirow[t]{2}{*}{ Workers' union (prior audit) } & $1.171 * * *$ & $0.551 *$ & $1.158 * * *$ & $1.002 * * *$ \\
\hline & $(0.113)$ & $(0.224)$ & $(0.117)$ & $(0.105)$ \\
\hline \multirow[t]{2}{*}{ Certification (prior audit) X Workers' union (prior audit) } & & $2.878^{* *}$ & & \\
\hline & & $(0.916)$ & & \\
\hline \multirow[t]{2}{*}{ Piece-rate payment (prior audit) } & $-3.626 * * *$ & $-3.678 * * *$ & $-3.836 * * *$ & $-4.060 * * *$ \\
\hline & $(0.881)$ & $(0.910)$ & $(0.972)$ & $(0.908)$ \\
\hline Piece-rate payment (prior audit) X Certification (prior audit) & & & $\begin{array}{c}1.062+ \\
(0.628)\end{array}$ & \\
\hline \multirow[t]{2}{*}{ Piece-rate payment (prior audit) X Workers' union (prior audit) } & & & & $1.119^{*}$ \\
\hline & & & & $(0.470)$ \\
\hline \multirow[t]{2}{*}{ Working condition score (prior audit) } & $-0.594 * * *$ & $-0.595 * * *$ & $-0.595 * * *$ & $-0.595 * * *$ \\
\hline & $(0.008)$ & $(0.008)$ & $(0.008)$ & $(0.008)$ \\
\hline \multirow[t]{2}{*}{ Rule of law (prior audit) ${ }^{\mathrm{S}}$} & $5.173 * * *$ & $5.279 * * *$ & $5.170 * * *$ & $5.166 * * *$ \\
\hline & $(0.891)$ & $(0.920)$ & $(0.888)$ & $(0.889)$ \\
\hline \multirow[t]{2}{*}{ Press freedom (prior audit) $\mathrm{S}$} & 1.061 & 0.933 & 1.068 & 1.056 \\
\hline & $(0.864)$ & $(0.841)$ & $(0.865)$ & $(0.865)$ \\
\hline \multirow[t]{2}{*}{ FDI inflow (prior audit) ${ }^{\mathrm{L}, \mathrm{S}}$} & -0.115 & -0.078 & -0.139 & -0.106 \\
\hline & $(0.986)$ & $(0.985)$ & $(0.984)$ & $(0.986)$ \\
\hline \multirow[t]{2}{*}{ Paid by buyer (prior audit) } & 0.239 & 0.243 & 0.241 & 0.227 \\
\hline & $(0.323)$ & $(0.316)$ & $(0.323)$ & $(0.326)$ \\
\hline \multirow[t]{2}{*}{ Paid by buyer (focal audit) } & $1.033^{*}$ & $1.035^{*}$ & $1.029 *$ & $1.029 *$ \\
\hline & $(0.453)$ & $(0.450)$ & $(0.453)$ & $(0.455)$ \\
\hline \multirow[t]{2}{*}{ All-female team (prior audit) } & -0.172 & -0.201 & -0.176 & -0.160 \\
\hline & $(0.202)$ & $(0.202)$ & $(0.201)$ & $(0.201)$ \\
\hline \multirow[t]{2}{*}{ All-female team (focal audit) } & $-0.499 *$ & $-0.516^{*}$ & $-0.497 *$ & $-0.496^{*}$ \\
\hline & $(0.217)$ & $(0.214)$ & $(0.217)$ & $(0.219)$ \\
\hline \multirow[t]{2}{*}{ Mixed-gender team (prior audit) } & $1.636^{* *}$ & $1.689 * *$ & $1.645 * *$ & $1.660 * *$ \\
\hline & $(0.588)$ & $(0.593)$ & $(0.586)$ & $(0.589)$ \\
\hline \multirow[t]{2}{*}{ Mixed-gender team (focal audit) } & $-4.077 * * *$ & $-4.046 * * *$ & $-4.074 * * *$ & $-4.081 * * *$ \\
\hline & $(0.632)$ & $(0.621)$ & $(0.631)$ & $(0.628)$ \\
\hline \multirow[t]{2}{*}{ Audit team average age (prior audit) } & $-0.083^{*}$ & $-0.087^{*}$ & $-0.083^{*}$ & $-0.081^{*}$ \\
\hline & $(0.038)$ & $(0.040)$ & $(0.038)$ & $(0.039)$ \\
\hline \multirow[t]{2}{*}{ Audit team average age (focal audit) } & $0.129 * * *$ & $0.127 * * *$ & $0.129 * * *$ & $0.129 * * *$ \\
\hline & $(0.034)$ & $(0.033)$ & $(0.033)$ & $(0.034)$ \\
\hline Audit team maximum tenure (prior audit) & $0.287 * * *$ & $0.288 * * *$ & $0.289 * * *$ & $0.286^{* * *}$ \\
\hline & $(0.059)$ & $(0.058)$ & $(0.058)$ & $(0.059)$ \\
\hline Audit team maximum tenure (focal audit) & $-0.337 * * *$ & $-0.340 * * *$ & $-0.337 * * *$ & $-0.338 * * *$ \\
\hline & $(0.064)$ & $(0.064)$ & $(0.064)$ & $(0.064)$ \\
\hline Supplier's size (prior audit) ${ }^{\mathrm{L}}$ & $0.338^{*}$ & $0.347^{*}$ & $0.340^{*}$ & $0.343^{*}$ \\
\hline & $(0.139)$ & $(0.146)$ & $(0.140)$ & $(0.139)$ \\
\hline Supplier's age (prior audit) ${ }^{\mathrm{L}}$ & -0.089 & -0.084 & -0.090 & -0.083 \\
\hline & $(0.156)$ & $(0.155)$ & $(0.157)$ & $(0.155)$ \\
\hline Female worker ratio (prior audit) & $3.946 * * *$ & $4.065 * * *$ & $3.973 * * *$ & $3.935 * * *$ \\
\hline & $(0.428)$ & $(0.435)$ & $(0.428)$ & $(0.424)$ \\
\hline Local worker ratio (prior audit) & $-0.363 * * *$ & $-0.413 * * *$ & $-0.365 * * *$ & $-0.343 * * *$ \\
\hline & $(0.100)$ & $(0.104)$ & $(0.100)$ & $(0.097)$ \\
\hline Use subcontractors (prior audit) & -0.027 & -0.023 & -0.039 & -0.021 \\
\hline & $(0.612)$ & $(0.617)$ & $(0.612)$ & $(0.613)$ \\
\hline Industry fixed effects & YES & YES & YES & YES \\
\hline Year fixed effects & YES & YES & YES & YES \\
\hline Audit-sequence fixed effects & YES & YES & YES & YES \\
\hline Supplier-country fixed effects & YES & YES & YES & YES \\
\hline Buyer-country fixed effects & YES & YES & YES & YES \\
\hline Observations & 4,887 & 4,887 & 4,887 & 4,887 \\
\hline R-squared & 0.401 & 0.401 & 0.401 & 0.401 \\
\hline
\end{tabular}

Note: Ordinary least squares (OLS) regression coefficients with standard errors clustered by supplier country in parentheses.

$* * * \mathrm{p}<0.001, * * \mathrm{p}<0.01, * \mathrm{p}<0.05,+\mathrm{p}<0.10$ (two-tailed tests).

$\mathrm{S}$ indicates standardized; $\mathrm{L}$ indicates logged; ${ }^{\mathrm{L}, \mathrm{S}}$ indicates logged, then standardized. 
Figure 1. Improvement rates are lower at suppliers with piece-rate payment schemes, but the gap is significantly smaller among certified suppliers.

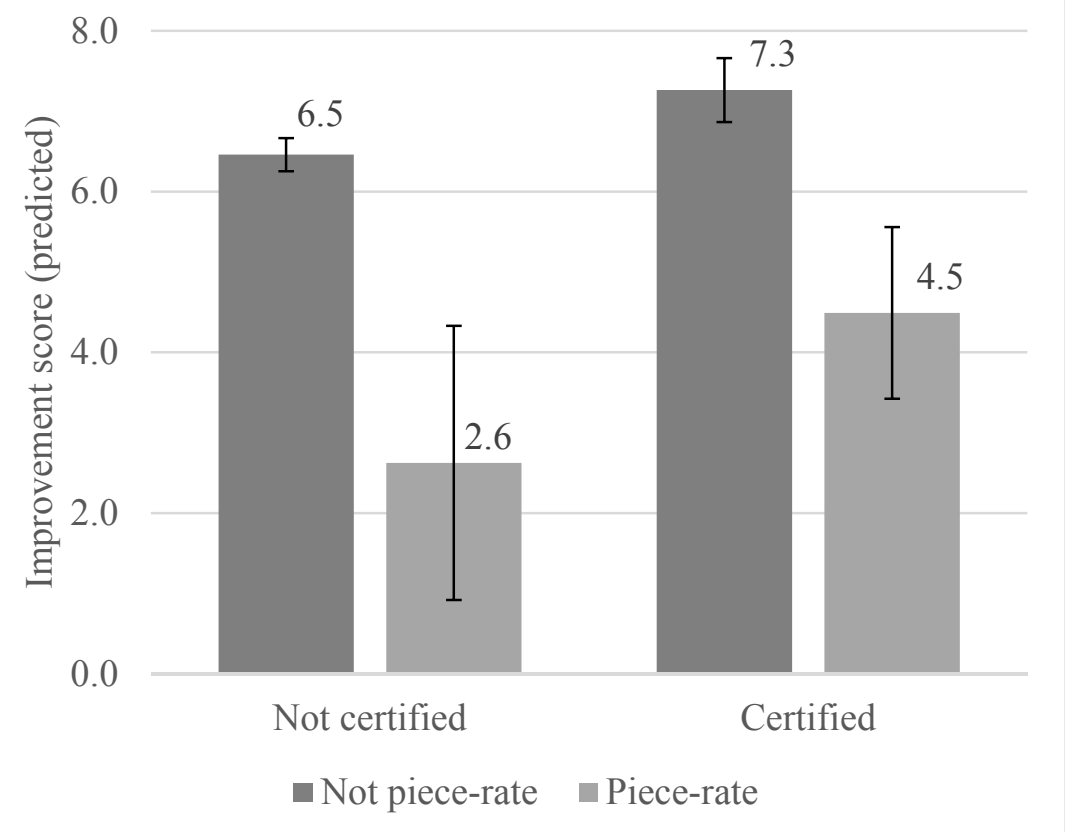

Note: This graph depicts average predicted effects and 95\% confidence intervals based on Model 3 in Table 5 .

Figure 2. Improvement rates are lower at suppliers with piece-rate payment schemes, but the gap is significantly smaller among unionized suppliers.

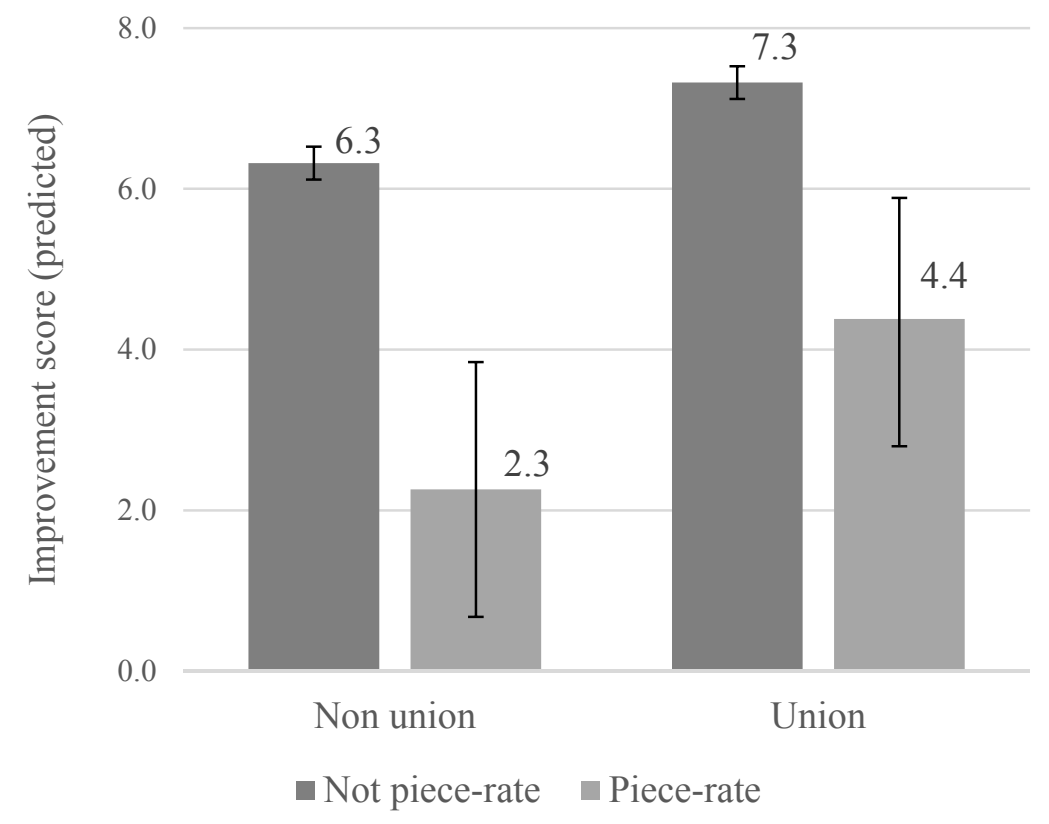

Note: This graph depicts average predicted effects and 95\% confidence intervals based on Model 4 in Table 5 . 


\section{Appendix B. Robustness Tests}

\section{Assessing the impact of including announcement information}

The auditing company that provided our data only began recording announcement information in 2014, midway through our sample period. To explore if omitting this information biased our results, we estimate our model on the subsample of audits conducted in 2014 and 2015, for which the announcement data was available. To provide a basis for comparison, we reestimated our primary direct model during this same period and report the results as Model 1 in Table B1. We then estimated the model including the two dummy variables, announced (prior audit) and announced (focal audit), in Model 2 in Table B1.

Overall, these two models yield very similar coefficients, magnitudes, and standard errors. Wald tests comparing our hypothesized coefficients across these models indicated that the coefficients on certification (prior audit) did not significantly differ (Wald $\chi^{2}=0.51, \mathrm{p}=0.48$ ). Neither did the coefficients on workers' union (prior audit) (Wald $\chi^{2}=0.00, \mathrm{p}=0.98$ ). The coefficient magnitude on piece-rate payment (prior audit) declined by a slight $2 \%{ }^{10}$ in the model that included announcement status. This small difference was statistically significant (Wald $\left.\chi^{2}=3.90, p=0.05\right)$, suggesting that omitting announcement status in our primary models might cause us to slightly underestimate the deleterious effect of piece-rate payment on improvement in working conditions.

\section{Assessing the impact of including the time gap between audits}

We estimate our primary models but predict improvement per month, which ranges from -1.4 to 6.5 and averages 1.5 (S.D. $=2.5$ ). The results continued to yield statistically significant coefficients of the same sign on most hypothesized effects, except for the coefficient of the interaction term piece-rate payment (prior audit) $\times$ certification (prior audit). One possible explanation is that in factories with efficiency incentives, the long-term benefits of a certified management system in tempering efficiency demands are more likely to be salient when the time gap between audits is greater.

\footnotetext{
${ }^{10}$ Calculated as $\left.(-3.06-(-2.99)) /(-2.99)\right)=2 \%$.
} 
Table B1. Regression Results

\begin{tabular}{|c|c|c|}
\hline Dependent variable: Improvement & $\begin{array}{c}\text { Omits } \\
\text { announcement } \\
(1) \\
\end{array}$ & $\begin{array}{c}\text { Includes } \\
\text { announcement } \\
(2)\end{array}$ \\
\hline Certification (prior audit) & $\begin{array}{l}1.755^{* *} \\
(0.521)\end{array}$ & $\begin{array}{l}1.743^{* *} \\
(0.521)\end{array}$ \\
\hline Workers' union (prior audit) & $\begin{array}{l}-0.038 \\
(0.231)\end{array}$ & $\begin{array}{l}-0.036 \\
(0.235)\end{array}$ \\
\hline Piece-rate payment (prior audit) & $\begin{array}{l}-2.994 * * * \\
(0.685)\end{array}$ & $\begin{array}{l}-3.064 * * * \\
(0.700)\end{array}$ \\
\hline Working condition score (prior audit) & $\begin{array}{l}-0.600 * * * \\
(0.018)\end{array}$ & $\begin{array}{l}-0.601^{* * *} \\
(0.018)\end{array}$ \\
\hline Rule of law (prior audit) ${ }^{S}$ & $\begin{array}{l}-43.259^{*} \\
(17.466)\end{array}$ & $\begin{array}{l}-42.291 * \\
(17.410)\end{array}$ \\
\hline Press freedom (prior audit) $\mathrm{S}$ & $\begin{array}{l}-24.836^{*} \\
(10.545)\end{array}$ & $\begin{array}{l}-24.377^{*} \\
(10.567)\end{array}$ \\
\hline FDI inflow (prior audit) ${ }^{\mathrm{L}, \mathrm{S}}$ & $\begin{array}{c}2.357 \\
(1.644)\end{array}$ & $\begin{array}{c}2.335 \\
(1.634)\end{array}$ \\
\hline Announced (prior audit) & & $\begin{array}{l}-1.710^{* *} \\
(0.515)\end{array}$ \\
\hline Announced (focal audit) & & $\begin{array}{l}-0.288 \\
(0.890)\end{array}$ \\
\hline Paid by buyer (prior audit) & $\begin{array}{l}1.873 * * * \\
(0.340)\end{array}$ & $\begin{array}{l}1.487 * * * \\
(0.341)\end{array}$ \\
\hline Paid by buyer (focal audit) & $\begin{array}{l}-0.994 * * \\
(0.341)\end{array}$ & $\begin{array}{l}-0.997 * \\
(0.425)\end{array}$ \\
\hline All-female team (prior audit) & $\begin{array}{l}-0.261 \\
(0.418)\end{array}$ & $\begin{array}{l}-0.247 \\
(0.403)\end{array}$ \\
\hline All-female team (focal audit) & $\begin{array}{l}-0.045 \\
(0.392)\end{array}$ & $\begin{array}{l}-0.050 \\
(0.393)\end{array}$ \\
\hline Mixed-gender team (prior audit) & $\begin{array}{l}2.118 * * * \\
(0.388)\end{array}$ & $\begin{array}{l}2.034 * * * \\
(0.391)\end{array}$ \\
\hline Mixed-gender team (focal audit) & $\begin{array}{l}-4.714 * * * \\
(0.589)\end{array}$ & $\begin{array}{l}-4.676^{* * *} \\
(0.599)\end{array}$ \\
\hline Audit team average age (prior audit) & $\begin{array}{l}-0.106^{*} \\
(0.043)\end{array}$ & $\begin{array}{l}-0.102 * \\
(0.044)\end{array}$ \\
\hline Audit team average age (focal audit) & $\begin{array}{l}0.143^{* * *} \\
(0.037)\end{array}$ & $\begin{array}{l}0.141^{* * *} \\
(0.037)\end{array}$ \\
\hline Audit team maximum tenure (prior audit) & $\begin{array}{l}0.218^{* *} \\
(0.076)\end{array}$ & $\begin{array}{l}0.214 * * \\
(0.078)\end{array}$ \\
\hline Audit team maximum tenure (focal audit) & $\begin{array}{l}-0.292^{*} \\
(0.111)\end{array}$ & $\begin{array}{l}-0.291^{*} \\
(0.112)\end{array}$ \\
\hline Supplier's size (prior audit) ${ }^{\mathrm{L}}$ & $\begin{array}{l}-0.099 \\
(0.101)\end{array}$ & $\begin{array}{l}-0.109 \\
(0.101)\end{array}$ \\
\hline Supplier's age (prior audit) ${ }^{\mathrm{L}}$ & $\begin{array}{l}-0.286 \\
(0.211)\end{array}$ & $\begin{array}{l}-0.296 \\
(0.212)\end{array}$ \\
\hline Female worker ratio (prior audit) & $\begin{array}{l}5.431 * * * \\
(0.643)\end{array}$ & $\begin{array}{l}5.427 * * * \\
(0.673)\end{array}$ \\
\hline Local worker ratio (prior audit) & $\begin{array}{l}-0.811^{* *} \\
(0.286)\end{array}$ & $\begin{array}{l}-0.840 * * \\
(0.287)\end{array}$ \\
\hline Use subcontractors (prior audit) & $\begin{array}{l}-0.574 \\
(0.491)\end{array}$ & $\begin{array}{l}-0.525 \\
(0.467)\end{array}$ \\
\hline Industry fixed effects & YES & YES \\
\hline Year fixed effects & YES & YES \\
\hline Audit-sequence fixed effects & YES & YES \\
\hline Supplier-country fixed effects & YES & YES \\
\hline Buyer-country fixed effects & YES & YES \\
\hline $\begin{array}{l}\text { Observations } \\
\text { R-squared }\end{array}$ & $\begin{array}{l}2,033 \\
0.45\end{array}$ & $\begin{array}{l}2,033 \\
0.45\end{array}$ \\
\hline
\end{tabular}

Note: Ordinary least squares (OLS) regression coefficients with standard errors clustered by supplier country in parentheses. Model 1 is estimated on the sample from 2014 to 2015 without the announcement information; Model 2 is estimated on the same sample, but includes the announcement information. ${ }^{* * *} \mathrm{p}<0.001, * * \mathrm{p}<0.01,{ }^{*} \mathrm{p}<0.05,+\mathrm{p}<0.10$ (two-tailed tests). ${ }^{\mathrm{S}}$ indicates standardized; L indicates logged; L,S indicates logged, then standardized. 
Table B2. Regression Results

\begin{tabular}{|c|c|c|c|c|}
\hline Dependent variable: Improvement per month & (1) & (2) & (3) & (4) \\
\hline \multirow[t]{2}{*}{ Certification (prior audit) } & $0.158^{* * *}$ & $0.095+$ & $0.163 * * *$ & $0.154 * * *$ \\
\hline & $(0.042)$ & $(0.050)$ & $(0.040)$ & $(0.041)$ \\
\hline \multirow[t]{2}{*}{ Workers' union (prior audit) } & $0.235 * * *$ & $0.202 * * *$ & $0.236 * * *$ & $0.208 * * *$ \\
\hline & $(0.031)$ & $(0.038)$ & $(0.032)$ & $(0.036)$ \\
\hline \multirow[t]{2}{*}{ Certification (prior audit) $\times$ Workers' union (prior audit) } & & $0.154 *$ & & \\
\hline & & $(0.065)$ & & \\
\hline \multirow[t]{2}{*}{ Piece-rate payment (prior audit) } & $-0.550 * * *$ & $-0.553 * * *$ & $-0.543 * * *$ & $-0.620 * * *$ \\
\hline & $(0.113)$ & $(0.114)$ & $(0.118)$ & $(0.116)$ \\
\hline \multirow[t]{2}{*}{ Piece-rate payment (prior audit) $\times$ Certification (prior audit) } & & & -0.037 & \\
\hline & & & $(0.073)$ & \\
\hline \multirow[t]{2}{*}{ Piece-rate payment (prior audit) $\times$ Workers' union (prior audit) } & & & & $0.181 *$ \\
\hline & & & & $(0.069)$ \\
\hline \multirow[t]{2}{*}{ Working condition score (prior audit) } & $-0.086 * * *$ & $-0.086^{* * *}$ & $-0.086 * * *$ & $-0.086 * * *$ \\
\hline & $(0.002)$ & $(0.002)$ & $(0.002)$ & $(0.002)$ \\
\hline \multirow[t]{2}{*}{ Rule of law (prior audit) ${ }^{\mathrm{S}}$} & $2.132 * * *$ & $2.138 * * *$ & $2.132 * * *$ & $2.131 * * *$ \\
\hline & $(0.272)$ & $(0.273)$ & $(0.272)$ & $(0.272)$ \\
\hline \multirow[t]{2}{*}{ Press freedom (prior audit) ${ }^{S}$} & $0.889 *$ & $0.882 *$ & $0.888 *$ & $0.888 *$ \\
\hline & $(0.423)$ & $(0.423)$ & $(0.423)$ & $(0.423)$ \\
\hline \multirow[t]{2}{*}{ FDI inflow (prior audit) ${ }^{\mathrm{L}, \mathrm{S}}$} & -0.374 & -0.372 & -0.373 & -0.373 \\
\hline & $(0.345)$ & $(0.345)$ & $(0.345)$ & $(0.345)$ \\
\hline \multirow[t]{2}{*}{ Paid by buyer (prior audit) } & $0.119 *$ & $0.119^{*}$ & $0.119 *$ & $0.117^{*}$ \\
\hline & $(0.047)$ & $(0.047)$ & $(0.047)$ & $(0.047)$ \\
\hline \multirow[t]{2}{*}{ Paid by buyer (focal audit) } & 0.124 & 0.124 & 0.124 & 0.123 \\
\hline & $(0.116)$ & $(0.116)$ & $(0.116)$ & $(0.116)$ \\
\hline \multirow[t]{2}{*}{ All-female team (prior audit) } & 0.011 & 0.009 & 0.011 & 0.013 \\
\hline & $(0.029)$ & $(0.029)$ & $(0.030)$ & $(0.029)$ \\
\hline \multirow[t]{2}{*}{ All-female team (focal audit) } & -0.071 & -0.072 & -0.072 & -0.071 \\
\hline & $(0.057)$ & $(0.057)$ & $(0.057)$ & $(0.057)$ \\
\hline \multirow[t]{2}{*}{ Mixed-gender team (prior audit) } & $0.490 * * *$ & $0.492 * * *$ & $0.489 * * *$ & $0.493 * * *$ \\
\hline & $(0.101)$ & $(0.101)$ & $(0.101)$ & $(0.101)$ \\
\hline \multirow[t]{2}{*}{ Mixed-gender team (focal audit) } & $-0.871 * * *$ & $-0.870 * * *$ & $-0.871 * * *$ & $-0.872 * * *$ \\
\hline & $(0.119)$ & $(0.119)$ & $(0.119)$ & $(0.119)$ \\
\hline \multirow[t]{2}{*}{ Audit team average age (prior audit) } & -0.010 & -0.010 & -0.010 & -0.010 \\
\hline & $(0.008)$ & $(0.008)$ & $(0.008)$ & $(0.008)$ \\
\hline \multirow[t]{2}{*}{ Audit team average age (focal audit) } & $0.020 * * *$ & $0.020 * * *$ & $0.020 * * *$ & $0.020 * * *$ \\
\hline & $(0.004)$ & $(0.004)$ & $(0.004)$ & $(0.004)$ \\
\hline Audit team maximum tenure (prior audit) & $0.055 * * *$ & $0.055 * * *$ & $0.055 * * *$ & $0.054 * * *$ \\
\hline & $(0.015)$ & $(0.015)$ & $(0.015)$ & $(0.015)$ \\
\hline Audit team maximum tenure (focal audit) & $-0.055 * * *$ & $-0.055 * * *$ & $-0.055 * * *$ & $-0.055 * * *$ \\
\hline & $(0.013)$ & $(0.013)$ & $(0.013)$ & $(0.013)$ \\
\hline Supplier's size (prior audit) ${ }^{\mathrm{L}}$ & $0.052 *$ & $0.052 *$ & $0.052 *$ & $0.053 *$ \\
\hline & $(0.023)$ & $(0.023)$ & $(0.023)$ & $(0.023)$ \\
\hline Supplier's age (prior audit) ${ }^{\mathrm{L}}$ & $-0.050+$ & $-0.050+$ & $-0.050+$ & -0.049 \\
\hline & $(0.030)$ & $(0.030)$ & $(0.030)$ & $(0.030)$ \\
\hline Female worker ratio (prior audit) & $0.438 * * *$ & $0.444 * * *$ & $0.437 * * *$ & $0.436 * * *$ \\
\hline & $(0.105)$ & $(0.105)$ & $(0.105)$ & $(0.105)$ \\
\hline Local worker ratio (prior audit) & $-0.061 * *$ & $-0.064 * *$ & $-0.061 * *$ & $-0.058 * *$ \\
\hline & $(0.020)$ & $(0.020)$ & $(0.020)$ & $(0.020)$ \\
\hline Use subcontractors (prior audit) & -0.015 & -0.015 & -0.014 & -0.014 \\
\hline & $(0.084)$ & $(0.084)$ & $(0.084)$ & $(0.084)$ \\
\hline Industry fixed effects & YES & YES & YES & YES \\
\hline Year fixed effects & YES & YES & YES & YES \\
\hline Audit-sequence fixed effects & YES & YES & YES & YES \\
\hline Supplier-country fixed effects & YES & YES & YES & YES \\
\hline Buyer-country fixed effects & YES & YES & YES & YES \\
\hline Observations & 4,887 & 4,887 & 4,887 & 4,887 \\
\hline R-squared & 0.411 & 0.411 & 0.411 & 0.411 \\
\hline
\end{tabular}

Note: Ordinary least squares (OLS) regression coefficients with standard errors clustered by supplier country in parentheses.

$* * * \mathrm{p}<0.001,{ }^{*} \mathrm{p}<0.01, * \mathrm{p}<0.05,+\mathrm{p}<0.10$ (two-tailed tests). ${ }^{\mathrm{S}}$ indicates standardized; $\mathrm{L}$ indicates logged; $\mathrm{L}, \mathrm{S}$ indicates logged, then standardized. 
Table C1. Certification Frequency

Panel A

\begin{tabular}{|c|c|c|c|c|c|c|}
\hline & \multicolumn{4}{|c|}{ Generative certifications } & \multirow{2}{*}{\multicolumn{2}{|c|}{ Total }} \\
\hline & \multicolumn{2}{|c|}{ No } & \multicolumn{2}{|c|}{ Yes } & & \\
\hline & Audits & Suppliers & Audits & Suppliers & Audits & Suppliers \\
\hline \multirow{2}{*}{$\begin{array}{l}\text { Prescriptive } \\
\text { certifications }\end{array}$} & 4,140 & 2,736 & 547 & 387 & 4,687 & 3,123 \\
\hline & 176 & 132 & 24 & 21 & 200 & 153 \\
\hline Total & 4,316 & 2,868 & 571 & 408 & 4,887 & 3,276 \\
\hline \multicolumn{7}{|c|}{$\begin{array}{rr}\text { Panel B } \\
\end{array}$} \\
\hline \multicolumn{3}{|c|}{ Prescriptive certifications } & \multicolumn{4}{|c|}{ Generative certifications } \\
\hline & Audits & Suppliers & & & Audits & Suppliers \\
\hline ICTI & 100 & 74 & ISO 9001 & & 421 & 306 \\
\hline SA 8000 & 48 & 33 & ISO 1400 & & 283 & 202 \\
\hline WRAP & 44 & 33 & ISO Othe & & 49 & 37 \\
\hline BSCI & 8 & 8 & OHSAS & 3001 & 67 & 58 \\
\hline \multirow[t]{5}{*}{ TLS } & 3 & 2 & BRC & & 40 & 29 \\
\hline & & & HACCP & & 28 & 18 \\
\hline & & & GB & & 29 & 20 \\
\hline & & & IFS & & 17 & 13 \\
\hline & & & FSSC & & 2 & 1 \\
\hline
\end{tabular}

Note: These tables report the number of audits and suppliers in our sample that have prescriptive and generative certifications. ICTI refers to International Council of Toy Industries. SA8000 refers to Social Accountability 8000. WRAP refers to Worldwide Responsible Accredited Production. BSCI refers to the Business Social Compliance Initiative. TLS refers to Thai Labor Standards. ISO 9001 is a Quality Management System Standard. ISO 14001 is an Environmental Management System Standard. Other ISO certifications include ISO TS 16949 (an application of the ISO 9001 Quality Management System Standard to the automotive industry), ISO 22000 (Food Safety Management System), ISO 27000 (Information Security Management System), and ISO 13485 (Quality Management System for Manufacturing Medical Device). OHSAS 18001 refers to Occupational Health and Safety Assessment Series 18001. BRC refers to British Retail Consortium. HACCP refers to Hazard Analysis and Critical Control Points. GB includes GB/T 28000 (the Chinese equivalent of OHSAS 18001), GB/T 24000 (the Chinese equivalent of ISO 14000), and GT/T 19000 (the Chinese equivalent of ISO 9000). IFS refers to International Featured Standards. FSSC refers to Food Safety System Certification. 
Table C2. Regression Results of Models Distinguishing Prescriptive and Generative Certification

\begin{tabular}{|c|c|c|c|c|c|c|c|}
\hline Dependent variable: Improvement & $(1)$ & $(2)$ & (3) & (4) & $(5)$ & (6) & $(7)$ \\
\hline Prescriptive certification (prior audit) & 0.413 & -0.328 & 0.427 & -0.327 & 0.230 & 0.421 & 0.230 \\
\hline Generative certification (prior audit) & $\begin{array}{l}(0.360) \\
1.025^{* * *} \\
(0.252)\end{array}$ & $\begin{array}{l}(0.487) \\
1.032^{* * *} \\
(0.256)\end{array}$ & $\begin{array}{l}(0.357) \\
-0.112 \\
(0.428)\end{array}$ & $\begin{array}{l}(0.490) \\
-0.113 \\
(0.433)\end{array}$ & $\begin{array}{l}(0.355) \\
1.035^{* * *} \\
(0.249)\end{array}$ & $\begin{array}{c}(0.358) \\
0.848^{* *} \\
(0.270)\end{array}$ & $\begin{array}{c}(0.353) \\
0.850^{* *} \\
(0.269)\end{array}$ \\
\hline Workers' union (prior audit) & $\begin{array}{l}1.159^{* * *} \\
(0.112)\end{array}$ & $\begin{array}{l}1.039^{* * *} \\
(0.130)\end{array}$ & $\begin{array}{l}0.739^{* * *} \\
(0.194)\end{array}$ & $\begin{array}{l}0.613 * * \\
(0.228)\end{array}$ & $\begin{array}{l}1.159^{* * *} \\
(0.112)\end{array}$ & $\begin{array}{l}1.148^{* * *} \\
(0.115)\end{array}$ & $\begin{array}{l}1.147^{* * *} \\
(0.115)\end{array}$ \\
\hline Workers' union (prior audit) $\times$ Prescriptive certification (prior audit) & & $\begin{array}{l}2.861 * * * \\
(0.799)\end{array}$ & & $\begin{array}{l}2.909 * * \\
(0.856)\end{array}$ & & & \\
\hline Workers' union (prior audit) $\times$ Generative certification (prior audit) & & & $\begin{array}{c}2.456^{*} \\
(0.980)\end{array}$ & $\begin{array}{c}2.474^{*} \\
(1.000)\end{array}$ & & & \\
\hline Piece-rate payment (prior audit) & $\begin{array}{l}-3.633^{* * *} \\
(0.881)\end{array}$ & $\begin{array}{l}-3.631 * * * \\
(0.88)\end{array}$ & $\begin{array}{l}-3.664 * * * \\
(0.904)\end{array}$ & $\begin{array}{l}-3.662^{* * * *} \\
(0.902)\end{array}$ & $\begin{array}{l}-3.705^{* * *} \\
(0.880)\end{array}$ & $\begin{array}{l}-3.824 * * * \\
(0.970)\end{array}$ & $\begin{array}{l}-3.907 * * * \\
(0.972)\end{array}$ \\
\hline Piece-rate payment (prior audit) $\times$ Prescriptive certification (prior audit) & & & & & $\begin{array}{c}2.367 * \\
(0.959)\end{array}$ & & $\begin{array}{c}2.473^{*} \\
(0.994)\end{array}$ \\
\hline Piece-rate payment (prior audit) $\times$ Generative certification (prior audit) & & & & & & $\begin{array}{c}1.136+ \\
(0.651)\end{array}$ & $\begin{array}{l}1.181+ \\
(0.659)\end{array}$ \\
\hline Working condition score (prior audit) & $\begin{array}{l}-0.594 * * * \\
(0.008)\end{array}$ & $\begin{array}{l}-0.594 * * * \\
(0.008)\end{array}$ & $\begin{array}{l}-0.595 * * * \\
(0.008)\end{array}$ & $\begin{array}{l}-0.595^{* * *} \\
(0.008)\end{array}$ & $\begin{array}{l}-0.595 * * * \\
(0.008)\end{array}$ & $\begin{array}{l}-0.594^{* * *} \\
(0.008)\end{array}$ & $\begin{array}{l}-0.595^{* * *} \\
(0.008)\end{array}$ \\
\hline Rule of law (prior audit) $\mathrm{s}$ & $\begin{array}{l}5.174 * * * \\
(0.893)\end{array}$ & $\begin{array}{l}5.210 * * * \\
(0.901)\end{array}$ & $\begin{array}{l}5.238^{* * * *} \\
(0.909)\end{array}$ & $\begin{array}{l}5.275^{* * * *} \\
(0.918)\end{array}$ & $\begin{array}{l}5.188 * * * \\
(0.885)\end{array}$ & $\begin{array}{l}5.165 * * * \\
(0.891)\end{array}$ & $\begin{array}{l}5.178^{* * * *} \\
(0.883)\end{array}$ \\
\hline Press freedom (prior audit) ${ }^{\mathrm{S}}$ & $\begin{array}{l}1.049 \\
(0.867)\end{array}$ & $\begin{array}{l}1.055 \\
(0.869)\end{array}$ & $\begin{array}{c}0.936 \\
(0.842)\end{array}$ & $\begin{array}{c}0.940 \\
(0.843)\end{array}$ & $\begin{array}{l}1.056 \\
(0.868)\end{array}$ & $\begin{array}{l}1.057 \\
(0.869)\end{array}$ & $\begin{array}{c}1.065 \\
(0.870)\end{array}$ \\
\hline FDI inflow (prior audit) ${ }^{\mathrm{L}, \mathrm{S}}$ & $\begin{array}{l}-0.114 \\
(0.988)\end{array}$ & $\begin{array}{l}-0.095 \\
(0.989)\end{array}$ & $\begin{array}{l}-0.097 \\
(0.987)\end{array}$ & $\begin{array}{l}-0.078 \\
(0.988)\end{array}$ & $\begin{array}{l}-0.110 \\
(0.988)\end{array}$ & $\begin{array}{l}-0.140 \\
(0.990)\end{array}$ & $\begin{array}{l}-0.138 \\
(0.988)\end{array}$ \\
\hline Paid by buyer (prior audit) & $\begin{array}{c}0.241 \\
(0.324)\end{array}$ & $\begin{array}{c}0.234 \\
(0.320)\end{array}$ & $\begin{array}{c}0.247 \\
(0.322)\end{array}$ & $\begin{array}{c}0.240 \\
(0.318)\end{array}$ & $\begin{array}{c}0.244 \\
(0.327)\end{array}$ & $\begin{array}{c}0.242 \\
(0.324)\end{array}$ & $\begin{array}{c}0.245 \\
(0.326)\end{array}$ \\
\hline Paid by buyer (focal audit) & $\begin{array}{c}1.034^{*} \\
(0.455)\end{array}$ & $\begin{array}{c}1.035^{*} \\
(0.452)\end{array}$ & $\begin{array}{c}1.026^{*} \\
(0.452)\end{array}$ & $\begin{array}{l}1.028^{*} \\
(0.449)\end{array}$ & $\begin{array}{c}1.028^{*} \\
(0.456)\end{array}$ & $\begin{array}{c}1.032 * \\
(0.455)\end{array}$ & $\begin{array}{c}1.026^{*} \\
(0.456)\end{array}$ \\
\hline All-female team (prior audit) & $\begin{array}{l}-0.175 \\
(0.202)\end{array}$ & $\begin{array}{l}-0.180 \\
(0.201)\end{array}$ & $\begin{array}{l}-0.196 \\
(0.203)\end{array}$ & $\begin{array}{l}-0.200 \\
(0.201)\end{array}$ & $\begin{array}{l}-0.181 \\
(0.203)\end{array}$ & $\begin{array}{l}-0.177 \\
(0.201)\end{array}$ & $\begin{array}{l}-0.183 \\
(0.202)\end{array}$ \\
\hline All-female team (focal audit) & $\begin{array}{l}-0.500^{*} \\
(0.216)\end{array}$ & $\begin{array}{l}-0.499^{*} \\
(0.215)\end{array}$ & $\begin{array}{l}-0.516^{*} \\
(0.218)\end{array}$ & $\begin{array}{l}-0.516^{*} \\
(0.217)\end{array}$ & $\begin{array}{l}-0.505^{*} \\
(0.216)\end{array}$ & $\begin{array}{l}-0.494^{*} \\
(0.215)\end{array}$ & $\begin{array}{l}-0.500^{*} \\
(0.215)\end{array}$ \\
\hline Mixed-gender team (prior audit) & $\begin{array}{l}1.648^{* *} \\
(0.597)\end{array}$ & $\begin{array}{l}1.641^{* *} \\
(0.595)\end{array}$ & $\begin{array}{l}1.696^{* *} \\
(0.602)\end{array}$ & $\begin{array}{l}1.690^{* *} \\
(0.601)\end{array}$ & $\begin{array}{l}1.645^{* *} \\
(0.596)\end{array}$ & $\begin{array}{l}1.658^{* *} \\
(0.596)\end{array}$ & $\begin{array}{l}1.654^{* *} \\
(0.594)\end{array}$ \\
\hline Mixed-gender team (focal audit) & $\begin{array}{l}-4.065^{* * * *} \\
(0.627)\end{array}$ & $\begin{array}{l}-4.090^{* * *} \\
(0.627)\end{array}$ & $\begin{array}{l}-4.030^{* * *} \\
(0.622)\end{array}$ & $\begin{array}{l}-4.055^{* * * *} \\
(0.622)\end{array}$ & $\begin{array}{l}-4.070^{* * * *} \\
(0.627)\end{array}$ & $\begin{array}{l}-4.061^{* * *} \\
(0.626)\end{array}$ & $\begin{array}{l}-4.066^{* * * *} \\
(0.626)\end{array}$ \\
\hline Audit team average age (prior audit) & $\begin{array}{l}-0.083^{*} \\
(0.038)\end{array}$ & $\begin{array}{l}-0.084^{*} \\
(0.038)\end{array}$ & $\begin{array}{l}-0.085^{*} \\
(0.040)\end{array}$ & $\begin{array}{l}-0.087^{*} \\
(0.040)\end{array}$ & $\begin{array}{l}-0.084 * \\
(0.038)\end{array}$ & $\begin{array}{l}-0.083^{*} \\
(0.038)\end{array}$ & $\begin{array}{l}-0.083^{*} \\
(0.038)\end{array}$ \\
\hline Audit team average age (focal audit) & $\begin{array}{l}0.130^{* * *} \\
(0.034)\end{array}$ & $\begin{array}{l}0.130^{* * *} \\
(0.034)\end{array}$ & $\begin{array}{l}0.127^{* * * *} \\
(0.034)\end{array}$ & $\begin{array}{l}0.128 * * * \\
(0.034)\end{array}$ & $\begin{array}{l}0.130^{* * *} \\
(0.034)\end{array}$ & $\begin{array}{l}0.130^{* * *} \\
(0.034)\end{array}$ & $\begin{array}{l}0.130^{* * *} \\
(0.034)\end{array}$ \\
\hline Audit team maximum tenure (prior audit) & $\begin{array}{l}0.290^{* * * *} \\
(0.059)\end{array}$ & $\begin{array}{l}0.290^{* * * *} \\
(0.059)\end{array}$ & $\begin{array}{l}0.288^{* * *} \\
(0.059)\end{array}$ & $\begin{array}{l}0.289 * * * \\
(0.059)\end{array}$ & $\begin{array}{l}0.289 * * * \\
(0.059)\end{array}$ & $\begin{array}{l}0.291 * * * \\
(0.059)\end{array}$ & $\begin{array}{l}0.291 * * * \\
(0.059)\end{array}$ \\
\hline Audit team maximum tenure (focal audit) & $\begin{array}{l}-0.338^{* * *} \\
(0.064)\end{array}$ & $\begin{array}{l}-0.339 * * * \\
(0.064)\end{array}$ & $\begin{array}{l}-0.339 * * * \\
(0.064)\end{array}$ & $\begin{array}{l}-0.341 * * * \\
(0.063)\end{array}$ & $\begin{array}{l}-0.338 * * * \\
(0.064)\end{array}$ & $\begin{array}{l}-0.337 * * * \\
(0.064)\end{array}$ & $\begin{array}{l}-0.337 * * * \\
(0.064)\end{array}$ \\
\hline Supplier's size (prior audit) ${ }^{\mathrm{L}}$ & $\begin{array}{c}0.344^{*} \\
(0.135)\end{array}$ & $\begin{array}{c}0.350^{*} \\
(0.137)\end{array}$ & $\begin{array}{c}0.344^{*} \\
(0.136)\end{array}$ & $\begin{array}{c}0.350^{*} \\
(0.139)\end{array}$ & $\begin{array}{c}0.345^{*} \\
(0.135)\end{array}$ & $\begin{array}{c}0.345^{*} \\
(0.135)\end{array}$ & $\begin{array}{c}0.346^{*} \\
(0.135)\end{array}$ \\
\hline Supplier's age (prior audit) ${ }^{\mathrm{L}}$ & $\begin{array}{l}-0.090 \\
(0.155)\end{array}$ & $\begin{array}{l}-0.092 \\
(0.155)\end{array}$ & $\begin{array}{l}-0.085 \\
(0.153)\end{array}$ & $\begin{array}{l}-0.086 \\
(0.153)\end{array}$ & $\begin{array}{l}-0.091 \\
(0.156)\end{array}$ & $\begin{array}{l}-0.090 \\
(0.156)\end{array}$ & $\begin{array}{l}-0.091 \\
(0.156)\end{array}$ \\
\hline Female worker ratio (prior audit) & $\begin{array}{l}3.980^{* * * *} \\
(0.423)\end{array}$ & $\begin{array}{l}3.964^{* * *} \\
(0.423)\end{array}$ & $\begin{array}{l}4.070^{* * *} \\
(0.433)\end{array}$ & $\begin{array}{l}4.053^{* * *} \\
(0.432)\end{array}$ & $\begin{array}{l}3.993^{* * * *} \\
(0.421)\end{array}$ & $\begin{array}{l}4.000^{* * *} \\
(0.423)\end{array}$ & $\begin{array}{l}4.013^{* * *} \\
(0.421)\end{array}$ \\
\hline Local worker ratio (prior audit) & $\begin{array}{l}-0.388^{* * * *} \\
(0.099)\end{array}$ & $\begin{array}{l}-0.382 * * * \\
(0.100)\end{array}$ & $\begin{array}{l}-0.418^{* * *} \\
(0.100)\end{array}$ & $\begin{array}{l}-0.413 * * * \\
(0.101)\end{array}$ & $\begin{array}{l}-0.391 * * * \\
(0.100)\end{array}$ & $\begin{array}{l}-0.384 * * * \\
(0.099)\end{array}$ & $\begin{array}{l}-0.386^{* * * *} \\
(0.100)\end{array}$ \\
\hline Use subcontractors (prior audit) & $\begin{array}{l}-0.029 \\
(0.615)\end{array}$ & $\begin{array}{l}-0.022 \\
(0.611)\end{array}$ & $\begin{array}{l}-0.028 \\
(0.619)\end{array}$ & $\begin{array}{l}-0.020 \\
(0.614)\end{array}$ & $\begin{array}{l}-0.035 \\
(0.611)\end{array}$ & $\begin{array}{l}-0.039 \\
(0.615)\end{array}$ & $\begin{array}{l}-0.045 \\
(0.611)\end{array}$ \\
\hline
\end{tabular}

sequence, supplier country, and buyer country. For all models, $\mathrm{N}=4,887$ and R-squared $=0.401$. S indicates standardized; L indicates logged; L,S indicates logged, then standardized. 